\title{
Influence of El Niño Wind Stress Anomalies on South Brazil Bight Ocean Volume Transports
}

\author{
Luiz Paulo de Freitas Assad, ${ }^{1}$ Carina Stefoni Böck, ${ }^{1}$ \\ Rogerio Neder Candella, ${ }^{2}$ and Luiz Landau ${ }^{1}$ \\ ${ }^{1}$ Universidade Federal do Rio de Janeiro, COPPE, Programa de Engenharia Civil, Laboratório de \\ Métodos Computacionais em Engenharia, Avenida Athos da Silveira Ramos 149, Cidade Universitária, Ilha do Fundão, \\ 21941-909 Rio de Janeiro, RJ, Brazil \\ ${ }^{2}$ Instituto de Estudos do Mar Almirante Paulo Moreira, Divisão de Oceanografia Física, Rua Kioto 253, Arraial do Cabo, \\ 28930-000 Rio de Janeiro, RJ, Brazil \\ Correspondence should be addressed to Carina Stefoni Böck; bock@lamce.coppe.ufrj.br
}

Received 3 July 2014; Revised 29 November 2014; Accepted 18 December 2014

Academic Editor: Swadhin Behera

Copyright ( 2015 Luiz Paulo de Freitas Assad et al. This is an open access article distributed under the Creative Commons Attribution License, which permits unrestricted use, distribution, and reproduction in any medium, provided the original work is properly cited.

\begin{abstract}
The knowledge of wind stress variability could represent an important contribution to understand the variability over upper layer ocean volume transports. The South Brazilian Bight (SBB) circulation had been studied by numerous researchers who predominantly attempted to estimate its meridional volume transport. The main objective and contribution of this study is to identify and quantify possible interannual variability in the ocean volume transport in the SBB induced by the sea surface wind stress field. A low resolution ocean global circulation model was implemented to investigate the volume transport variability. The results obtained indicate the occurrence of interannual variability in meridional ocean volume transports along three different zonal sections. These results also indicate the influence of a wind driven large-scale atmospheric process that alters locally the SBB and near-offshore region wind stress field and consequently causes interannual variability in the upper layer ocean volume transports. A strengthening of the southward flow in $25^{\circ} \mathrm{S}$ and $30^{\circ} \mathrm{S}$ was observed. The deep layer ocean volume transport in the three monitored sections indicates a potential dominance of other remote ocean processes. A small time lag between the integrated meridional volume transports changes in each monitored zonal section was observed.
\end{abstract}

\section{Introduction}

Very little is known about the influence of the wind stress field over the upper ocean volume transport in the South Brazil Bight (SBB) and the interannual variability associated with them.

One of the most important oceanographic features of the SBB is the Brazil Current (BC). This current flows along most part of the Brazilian tropical and subtropical continental shelf and the adjacent offshore region, and it is one of the major currents associated with the South Atlantic subtropical gyre (SASG) ocean circulation system. The BC has been studied by numerous researchers who predominantly attempted to estimate its meridional volume transport based on hydrographic datasets acquired at different latitudes $[1,2]$. Only a few studies in the scientific literature treat specifically about the interannual variability of the $\mathrm{BC}$ volume transport even though many studies describing general dynamic aspects in different variability scales for the whole South Atlantic basin had been published such as Schott et al. [3], Stramma et al. [4], Lumpkin and Garzoli [5] and Veleda et al. [6]. Goni et al. [7], using satellite-derived sea height anomaly and sea surface temperature (SST) observations from 1993 to 2008 , observed low-frequency variability of the BC front. The authors were not able to observe statistically significant changes in BC geostrophic transport, suggesting that the lowfrequency changes in the $\mathrm{BC}$ front are governed by different mechanisms compared to the seasonal variability of the surface currents. The authors suggested the analysis of longer records, together with comprehensive numerical experiments 
using state-of-the-art ocean models, to determine the origin of these variabilities.

The region where the $\mathrm{BC}$ is located presents a complex vertical extension composed of different water masses that, in some regions, flow in opposite directions. The $\mathrm{BC}$ is important for understanding the South American and especially the Brazilian climate because of its important contribution as a source of sea surface temperature variability in the region. Cataldi et al. [8], using an atmospheric general circulation model (AGCM) forced with synthetic SST anomaly fields from observed data in BMC region, observed a strong correlation between positive SST anomalies near the Brazil Malvinas confluence (BMC) region and the hydrometeorological regime over the south and southeast Brazilian regions. This motivates the need to better understand how the upper layer transports would vary under the influence of interannual wind stress variability.

The ENSO-driven, large-scale atmospheric teleconnections alter the near-surface air temperature, humidity, and wind, in addition to the distribution of clouds far from the Equatorial Pacific. The resulting variations in the surface heat, momentum, and freshwater fluxes can induce changes in the SST, salinity, mixed layer depth (MLD), and ocean currents [9]. Vivier et al. [10], studying time series of current meter data located in the BMC region, pressure sensor data sets located in the Drake Passage and a five year Malvinas Current (MC) transport series, observed an important annual variability signal. The authors suggested that the main source of BMC front movements is the BC. Lentini et al. [11], studying sea surface temperature variability in the southwestern Atlantic region from thirteen years remote sensing data set, observed a northward (southward) advection of cold (warm) anomalies $\left( \pm 1^{\circ} \mathrm{C}\right)$ during and immediately after warm (cold) phases of the ENSO and noted that the larger amplitudes of these anomalies were situated at the La Plata River and the Patos Lagoon offshore regions.

The South Atlantic basin large scale atmospheric circulation could be influenced by remote ocean-atmosphere processes. Torres Jr. [12], using an AGCM to force an Oceanic General Circulation Model (OGCM), demonstrated that on seasonal and interannual scales, the SASH is sensitive to the occurrence of sea surface anomalies in the Equatorial Pacific. The author also observed changes in Hadley and Walker circulations that influenced the SASH behavior and consequently increased the $\mathrm{BC}$ and $\mathrm{MC}$ transports.

Assad et al. [13] studied the influence of an ENSO-type global wind stress field that was represented by a monthly mean global wind stress field where it was introduced anomaly signals related with 1982-1983 ENSO event. The results revealed the occurrence of positive SST anomalies, near the BMC region associated with upper ocean velocity anomalies. The occurrence of positive anomalies was always associated with an enhanced BC meridional surface volume transport, together with a decrease of the ACC zonal volume transport, vertically integrated across the Drake Passage, and a correspondent decrease in the upper layer MC volume transport. It was possible to see negative upper layer temperature anomaly predominance just before the peak ocean kinetic energy month and positive anomaly predominance immediately following this month.

Most of the knowledge that exists about the seasonality of $\mathrm{BC}$ volume transport was obtained by the application of the geostrophic method using in situ temperature and salinity data collected along the Brazilian coast and the adjacent offshore region [2]. This method effectively determines numerous dynamic ocean properties and has historical importance in understanding features of the global ocean circulation. However, this method has several intrinsic problems in determining the zero-motion level, which is fundamental for its application. This fact explains the discrepancies in volume transport estimates for the same region, which are commonly found in the literature. This problem is minimized when volume transport estimates are obtained by a numerical deterministic ocean model, which allows for the direct identification of the zero-motion level in the water column.

The main objective and contribution of this study is to identify and quantify possible interannual variability in the ocean volume transport in the SBB in the region confined between $23^{\circ} \mathrm{S}$ and $30^{\circ} \mathrm{S}$, in response to a transient three year global wind stress field. The results obtained clearly indicate the occurrence of interannual variability in BC volume transport when the three-dimensional field is analyzed. These results also indicate the influence of a wind-driven, largescale atmospheric teleconnection process that alters the SBB and near-offshore region wind stress field and consequently causes interannual variability in the upper layer volume transports.

\section{Study Area}

The SBB is defined as the region of the southwestern Brazilian continental shelf extending from Cabo de São Tomé $\left(22^{\circ} \mathrm{S}-\right.$ $\left.41^{\circ} \mathrm{W}\right)$ to Cabo de Santa Marta $\left(28.63^{\circ} \mathrm{S}-48.75^{\circ} \mathrm{W}\right)[14]$.

The $\mathrm{BC}$ is characterized by the vertical stacking of four water masses in the first 3000 meters: Tropical Water (TW), South Atlantic Central Water (SACW), Antarctic Intermediate Water (AIW) and North Atlantic Deep Water (NADW) [2]. According to Peterson and Stramma [1], the $\mathrm{BC}$ is formed just a few degrees south of the equator in the South Equatorial Current (SEC) bifurcation region. In fact, the southern branch of the SEC (the SSEC) forms the BC. Near this region, the $\mathrm{BC}$ flow is shallow and transports warm and salty water, which is represented by the TW in the upper 150 meters of depth, with an approximate volume transport of $4 \mathrm{~Sv}$. The surface portion of this current reaches the South American coast at approximately $15^{\circ} \mathrm{S}$ [15].

Notably, most of the water volume transported by the SSEC turns northward, feeding the North Brazil Current (NBC) [16]. This fact explains the occurrence of a weak southward volume transport in this region. Between $15^{\circ} \mathrm{S}$ and $20^{\circ} \mathrm{S}$, the $\mathrm{BC}$ flow remains weak, with values less than or equal to $11 \mathrm{~Sv}$. Miranda and Castro [17] estimated a value of $6.5 \mathrm{~Sv}$ for a section at $19^{\circ} \mathrm{S}$. On the offshore region near the city of Cabo Frio at $23^{\circ} \mathrm{S}$, several measures show that the volume transport reaches $11 \mathrm{~Sv}$, with more than half of the flow confined to the first 200 meters [1]. South of $24^{\circ} \mathrm{S}$, the BC increases its transport. This fact is associated 
with an anticyclonic recirculation cell that is observed in hydrographic measures [1]. Several estimates of this recirculation cell obtained values of $7.5 \mathrm{~Sv}$ for the first 800 meters, which causes an increase in the volume transport at $33^{\circ} \mathrm{S}$ of approximately $18 \mathrm{~Sv}$. This circulation is associated with the SACW that enters the subtropical ocean gyre after its formation at the BMC region. When the SACW reaches the South American coast, it bifurcates at approximately $20^{\circ} \mathrm{S}$, where part of its volume flows to the north and the other part flows to the south [18]. Stramma and England [18] synthesizes the circulation associated with the western boundary current system flowing along the Brazilian coast.

Stramma and England [18] presented schematic circulation diagrams based on observational data sets from different depths of the South Atlantic Ocean basin. The authors suggested an anticyclonic recirculation cell directly influenced by the SASG, where the SACW flows and, near the Brazil coast, feeds up into the BC flow between $20^{\circ} \mathrm{S}$ and $25^{\circ} \mathrm{S}$ at depth ranging between 100 and 500 meters. Below the SACW level, the authors observed the AIW that also follows the SASG and also feeds up into the BC flow farther south near $28^{\circ} \mathrm{S}$ in depths ranging between 500 and 1000 meters.

\section{Methodology}

The methodology of this work consists on estimating the $\mathrm{BC}$ system region volume ocean transports estimated along three zonal sections (furthered described) using the Modular Ocean Model 4.0 (MOM). MOM was developed at the Geophysical Fluid Dynamics Laboratory (GFDL) and has been largely used by the scientific community for global climatic research investigations and forecasts [19].

The numerical grid used had space resolution capable to resolve the main low frequency ocean processes presented in the whole South Atlantic Ocean Basin. In this grid, the world ocean is represented by a discrete integration domain with a horizontal resolution of $1^{\circ}$ longitude $\times 1^{\circ}$ latitude but increasing to $1 / 3^{\circ}$ of latitudinal resolution within the $10^{\circ} \mathrm{N}-$ $10^{\circ} \mathrm{S}$ equatorial band, with 360 longitudinal points and 200 latitudinal points composing the horizontal grid. Figure 1 shows the study area with the zonal cross-sections used for the volume transport analysis. The $z$ vertical coordinate layers vary in thickness to accommodate higher resolution near the surface of the ocean. There are 50 vertical layers, with 22 layers confined within the first 220 meters. Regions with depths smaller than 40 meters were not considered in the model calculations.

Two experiments, named the control and perturbed experiments, were performed. The control experiment reproduced the mean seasonal cycle behavior of BC volume transport along the zonal sections (Figure 1). In the perturbed experiment, ocean volume transport fields were produced by forcing the model with an anomalous sea surface wind stress field. The two experiments are detailed in the following sections.

3.1. Control Experiment. Cyclic boundary conditions were imposed on the model until it reached the desired climate, or stable state [20]. The data used as sea surface boundary conditions were taken from the climatologic data set of the Ocean Model Intercomparison Project (OMIP) [21]. OMIP data set was produced to generate robust boundary conditions to be used on oceanic numerical model experiments. The atmospheric variables used to force the model were the meridional and zonal wind stress components, shortwave and net longwave radiation, sensible heat flux, specific humidity flux, and frozen and liquid precipitation. The OMIP product consisted of daily means of an annual cycle, except for the specific humidity and sensible heat flux data, which were represented by the monthly means of an annual cycle.

The experiment used, as its initial condition, the ocean data (sea surface elevation, temperature, salinity and velocity fields) obtained from the ocean data assimilation for seasonal-to-interannual prediction (ODASI) experiment conducted by GFDL [22]. The ODASI experiment also used the MOM 4.0 code and generated 40 years of monthly average ocean data between 1963 and 2003. An assimilation ocean data system was employed during the model integration. The assimilation was conducted only between the years 1993 and 2001. ODASI data was chosen because of its capacity to reproduce the most important features of an ocean in thermodynamic and dynamic equilibrium and a reasonable "ocean climate" state. As the main idea of this work is to investigate the interannual variability of the BC system ocean volume transports exclusively due to wind stress field influence, the mass and velocity fields from January 1985 were chosen as initial boundary conditions. The choice of these fields was justified to ensure the absence of any strong global climate variability processes over such as ENSO over the ocean model prognostic fields.

3.2. Perturbed Experiment. The main goal of this experiment was to identify interannual variability in $\mathrm{BC}$ volume transport induced by a three-year transient wind stress field. The perturbed experiment used September monthly mean of dynamic and thermodynamic fields generated by the control experiment as initial conditions, but with only anomalous wind stress boundary conditions. These anomalous boundary conditions were determined by the monthly mean of global wind stress fields generated by an AGCM. The AGCM was integrated for three years, and it used Pacific Equatorial SST synthetic fields as boundary conditions based on the 19821983 ENSO event $[12,13,23]$. The choice of a three year period wind stress field was justified because it presented the same duration of the Equatorial Pacific SST anomaly pulse observed for the 1982-1983 ENSO event.

Those anomalous contour conditions were obtained through the monthly mean of global wind stress fields resulting from the difference between the results of two experiments which were carried out using the National Center of Atmospheric Research (NCAR) atmospheric general circulation model Community Climate Model (CCM 3.0), the climatologic (control experiment) and another one with a perturbed condition originated from a SST analytical anomaly, overlapping the field of the mean SST, both experiments being integrated for three years.

The synthetic SST fields were chosen because they allow an independent evaluation of the SST influence on the 
atmospheric dynamics of the studied region without taking into consideration other perturbations in the oceans, in the cryosphere or in the internal atmosphere structure itself [8].

The SST anomalies synthetic fields were obtained fitting the combination of two Gaussian distributions in space (1) and one in time (2), according to Torres Jr. [12] suggested methodology. Consider

$$
f(x)=\frac{1}{\sigma_{\varphi} \sqrt{2 \pi}} \exp \left[\frac{\left(y-\eta_{\varphi}\right)^{2}}{2 \sigma_{\varphi}^{2}}\right] \frac{1}{\sigma_{\lambda} \sqrt{2 \pi}} \exp \left[\frac{\left(x-\eta_{\lambda}\right)^{2}}{2 \sigma_{\lambda}^{2}}\right] .
$$

In which $f(x)$ is Gaussian space distribution function; $x$ is longitude index; $y$ is latitude index; $\eta_{\varphi}$ is latitude displacement; $\sigma_{\varphi}$ is latitude variance; $\eta_{\lambda}$ is longitude displacement; $\sigma_{\lambda}$ is longitude variance. Consider

$$
g(x)=\frac{1}{\sigma_{\tau} \sqrt{2 \pi}} \exp \left[\frac{\left(t-\eta_{\tau}\right)^{2}}{2 \sigma_{\tau}^{2}}\right] .
$$

In which $g(x)$ is Gaussian time distribution function; $t$ is time index; $\eta_{\tau}$ is time displacement; $\sigma_{\tau}$ is time variance or pulse width.

The adjustment was done based on the SST NASA/jet propulsion laboratory (JPL) via satellite data and the chosen ENSO event to adjust the function was the one from years $1982 / 1983$ which is considered as one of the most intense ENSO events recorded in the recent decades, and which was responsible for severe climatic impacts such as extreme wet weather in parts of the Americas and, concurrently, severe drought in parts of Australia and Asia [24].

The global ocean model was integrated for 36 months in this experiment. The annual mean values for volume transports in each section were subsequently estimated and analyzed. The main idea in the perturbed experiment is not getting the balance, as in the control experiment, but understand how volume transports will vary over the three years in response to a transient wind stress field.

3.3. Volume Transport Estimates. The position and geometry of each zonal section was chosen to cover the BC flow, considering its meridional and zonal extension between $23^{\circ} \mathrm{S}$ and $30^{\circ} \mathrm{S}$. Each section had its own geometry based on the surface annual mean BC meridional velocity profile and flow width obtained in the climate experiment. Three zonal sections were chosen (Figure 1). The choice of these sections is justified by the existence of some historical volume transport estimates near them $[1,2]$. Table 1 shows the exact coordinates of each section (latitude and longitude limits).

The volume transport estimates for each zonal section were performed using (3) and are expressed in Sverdrup $\left(\mathrm{Sv}=10^{6} \mathrm{~m}^{3} \cdot \mathrm{s}^{-1}\right)$. Consider

$$
v_{t}=\int_{0}^{L} \int_{-h(x)}^{0} v(x, z, t) d z d x
$$

$v_{t}$ is the volume transport (Sv), $L$ is the section width, $-h(x)$ is the depth, $v$ is the meridional velocity $(\mathrm{m} / \mathrm{s}), z$ is the

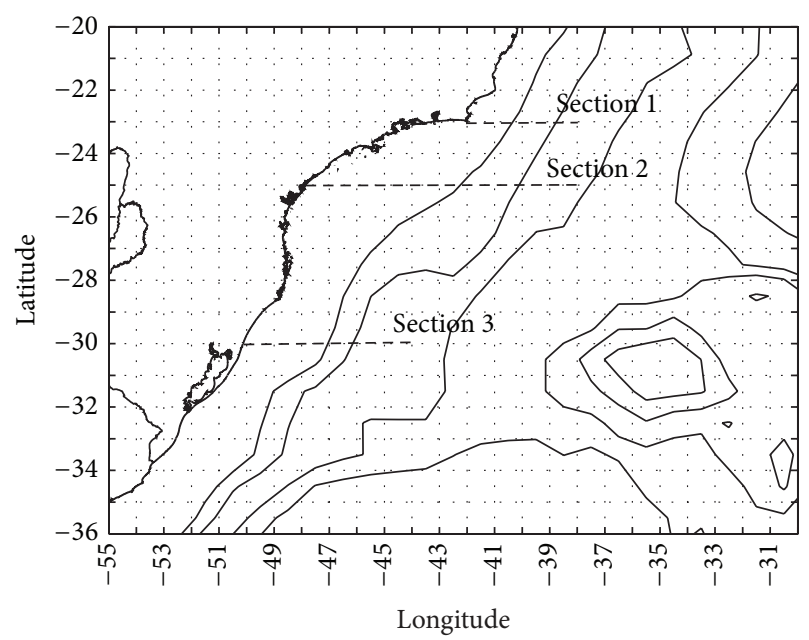

FIGURE 1: The study area comprising the SBB with the position of the three monitored zonal sections (1,2 and 3$)$. Isobathymetric lines are also presented.

TABle 1: Coordinates and thickness of each monitored section. The longitude values represent the exact offshore limit of the section.

\begin{tabular}{lccc}
\hline Section & Latitude & Longitude & Thickness (meters) \\
\hline Section 1 & $23^{\circ} \mathrm{S}$ & $38^{\circ} \mathrm{W}$ & 298.3 \\
Section 2 & $25^{\circ} \mathrm{S}$ & $38^{\circ} \mathrm{W}$ & 335.7 \\
Section 3 & $30^{\circ} \mathrm{S}$ & $44^{\circ} \mathrm{W}$ & 524.2 \\
\hline
\end{tabular}

depth ( $\mathrm{m})$ and $x$ is the zonal distance delimited exactly by the meridional limit of each section presented in Table 1.

The volume transport components were estimated over the meridional direction because of the mainly north-south direction of the $\mathrm{BC}$ flow in the studied region. Equation (1) was vertically integrated between the surface and the climate experiment annual mean level, where the meridional velocities were zero in each section. This level was chosen following Zemba (1991, in [2]), who considered kinematic criteria to define the current. Following this approach, the current can be defined as the total continuous flux flowing in the same direction as the surface current. In the studied region, this flux would represent the water volume transported south by the BC. The thickness of each section that was considered in the volume transport estimates was extracted from these profiles and represented the meridional volume transport zero-motion level (Table 1). The climate meridional volume transport vertical distribution in each section demonstrates a deepening of the meridonal volume transport no-motion level to the south (Figure 2).

The meridional volume transport anomaly fields for each section were also estimated. The anomaly values represent the difference between the annual mean perturbed experiment values and the same values obtained for the climate experiment. Importantly, negative (positive) meridional volume transport values represent southward (northward) flow direction and the occurrence of negative (positive) anomaly values in these regions represent an increase of the southward 


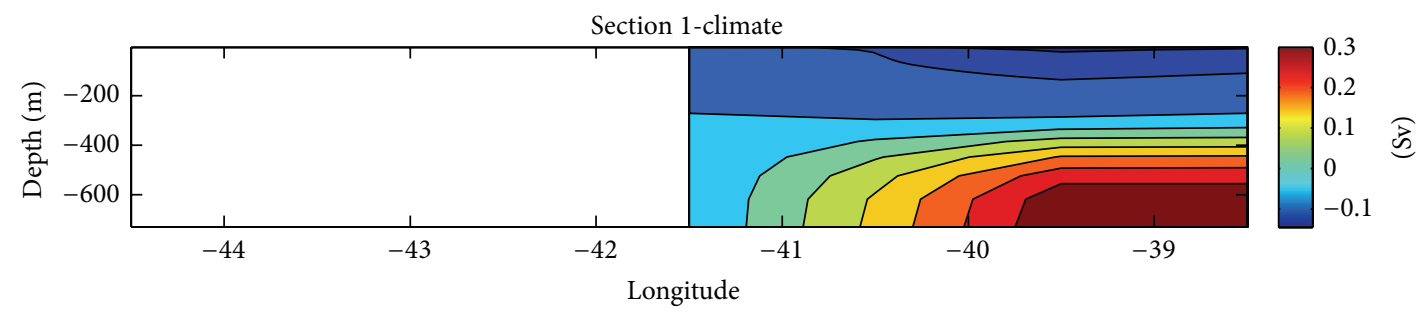

(a)

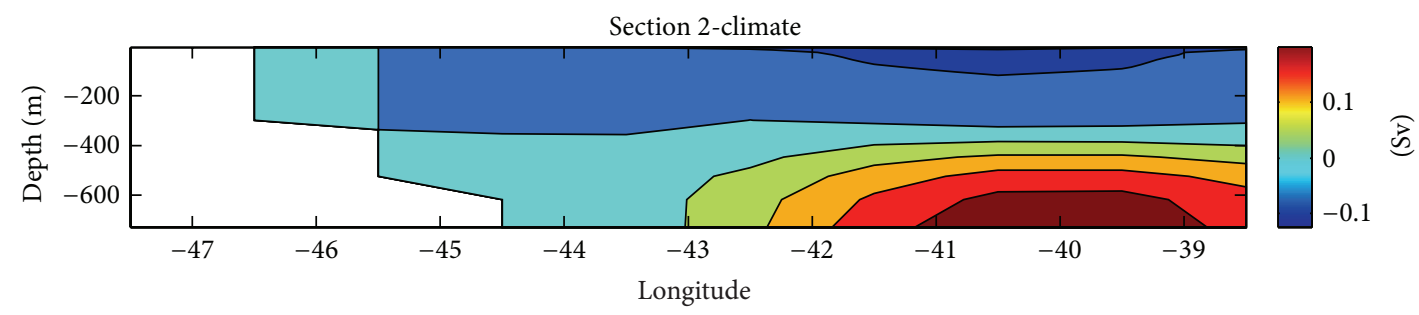

(b)

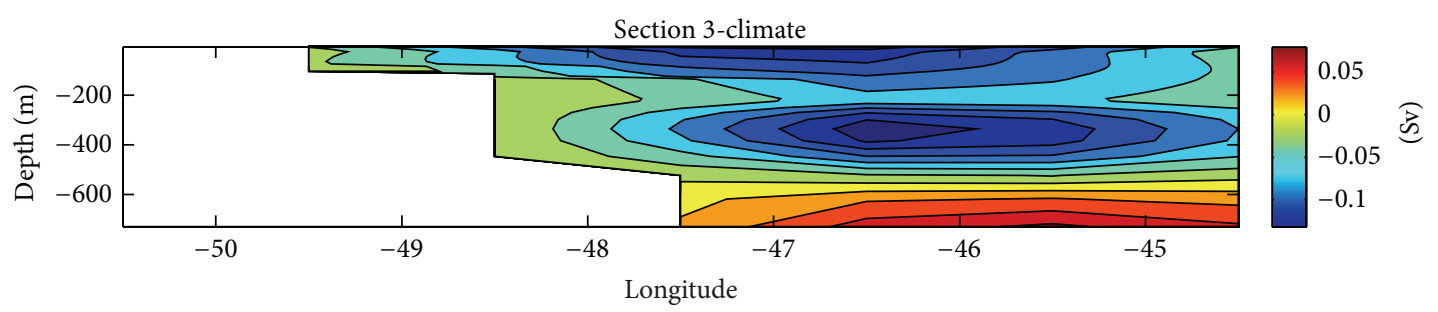

(c)

FIGURE 2: Annual mean vertical meridional volume transport distribution in Sections 1 (a), 2 (b), and 3 (c) obtained by the climate experiment. Sections are showed in Figure 1.

(northward) velocity field. This methodology was also applied to produce the volume transport anomaly vector fields.

\section{Results}

4.1. Control Experiment. The annual mean volume transport fields for the entire SBB area at the three different vertical layers defined in Table 1 are presented in Figure 3. It is possible to observe the most intense volume transport fields in the upper layer. It is also possible to observe the strengthening of southward flow toward the higher latitudes. This fact could be explained, in part, by the deepening of the no-motion level toward the same direction and a consequently greater southward water volume transported by the BC. It is also possible to observe the presence of the bifurcation zones associated with the anticyclonic circulation that occurs in different water layers along SBB region feeding BC southward flow in higher latitudes and the northward NBC flow in lower latitudes (Figure 3). This behavior was observed in Figure 2 where the deepening of the zero-motion level associated with the deepening and strengthening (higher negative values indicate stronger southward flow) of the southward BC flow toward higher latitudes was found [25]. In Sections 1 and 2 , it is still possible to observe positive meridional velocity values below 300 meters depth, indicating the presence of the northward flow that will feed the NBC flow at lower latitudes.
Generally, classical seasonal behavior was observed, with enhanced southward transports during austral summer months (December-January-February) and decreasing southward volume transport during austral winter months (June-July-August), as shown in Figure 4. The analysis of these time series plots revealed again an increase of the ocean volume transports toward the higher latitudes. Section 1 presented a minimum magnitude of $-4.0 \mathrm{~Sv}$ in July and a maximum magnitude of $-5.0 \mathrm{~Sv}$ in February. Section 2 presented a minimum volume transport magnitude of $-5.0 \mathrm{~Sv}$ in June and a maximum magnitude of $-6.7 \mathrm{~Sv}$ in February. Section 3 presented a minimum magnitude of $-7.0 \mathrm{~Sv}$ in June and a maximum magnitude of $-9.0 \mathrm{~Sv}$ in January. This analysis also revealed a representative climatological time lag between the seasonal cycles of the ocean volume transports in each section. For example, a time lag of one month between the minimum southward transport magnitude was observed in Section 1 compared to Section 2 and 3. Section 1 reached the minimum magnitude during July. Sections 2 and 3 reached their minimum southward magnitudes during June. Additionally, the maximum southward magnitude (more negative) of Sections 1 and 2 occur in February, whereas Section 3 reaches the largest magnitudes in January.

In Section 1, it is possible to observe the dominance of the southward flow at the surface (upper layers). The annual mean of the southward meridional transport reaches 


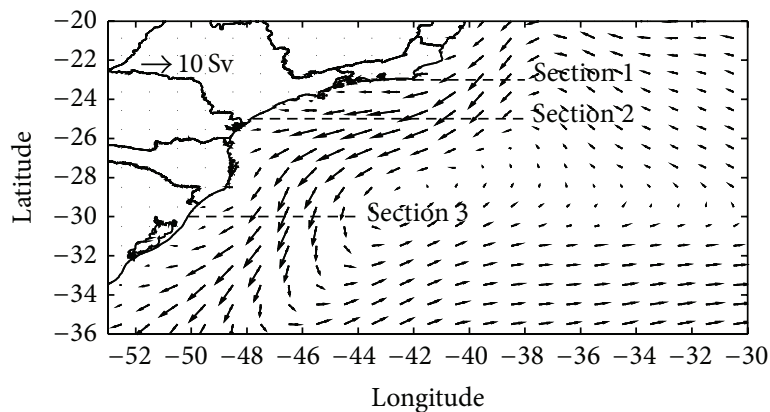

(a)

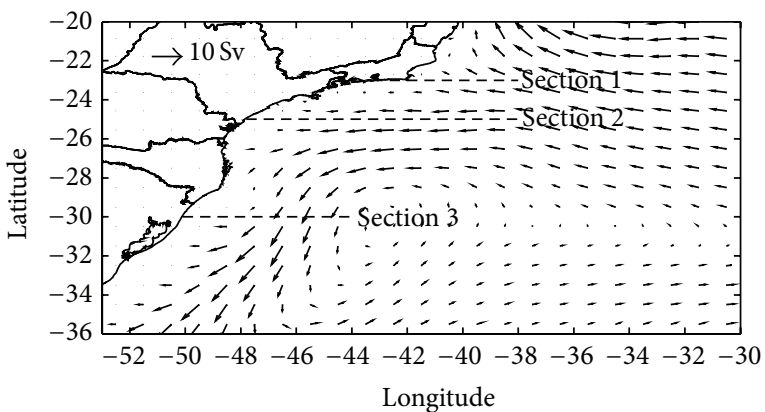

(b)

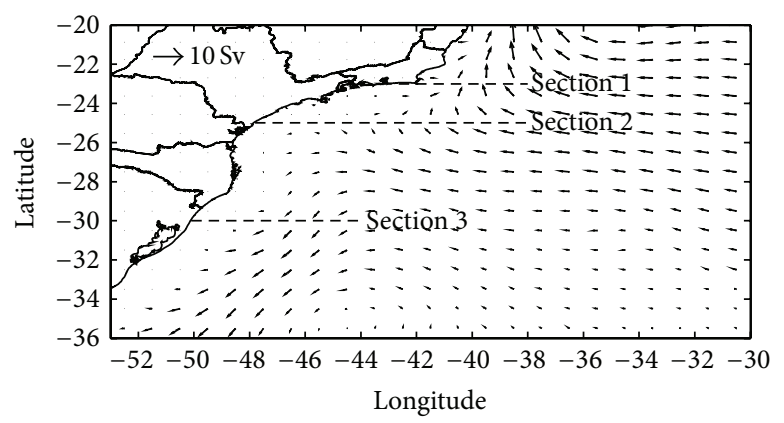

(c)

Figure 3: Climate annual mean integrated volume transport for 0-298.3 meters (a), 298.3-335.7 meters (b), and 335.7-524.2 meters (c).

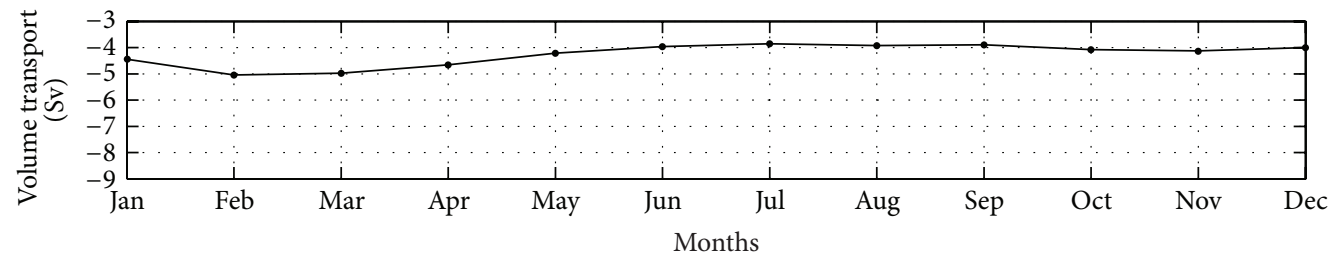

(a)

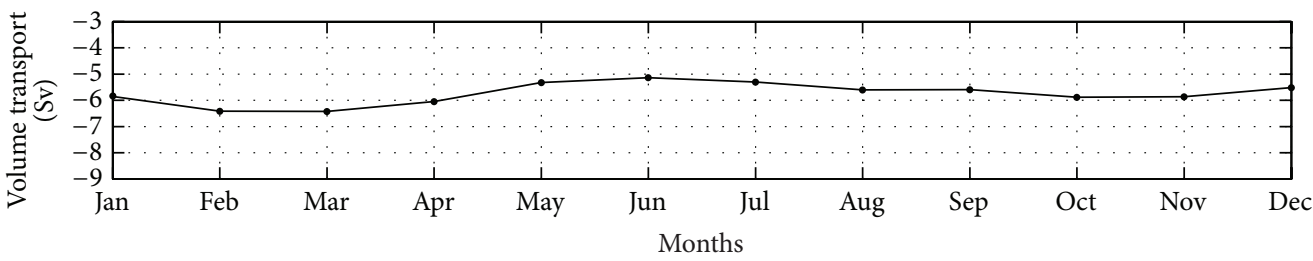

(b)

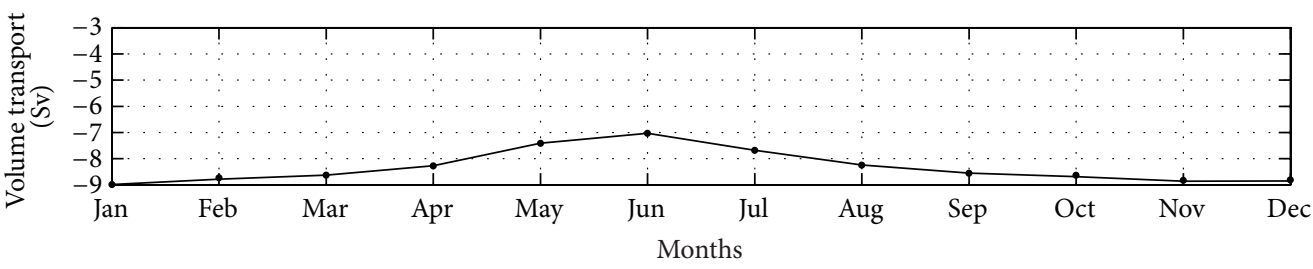

(c)

FIgURE 4: Time series of monthly mean meridional volume transport vertically integrated for Sections 1 (a), 2 (b), and 3 (c). 


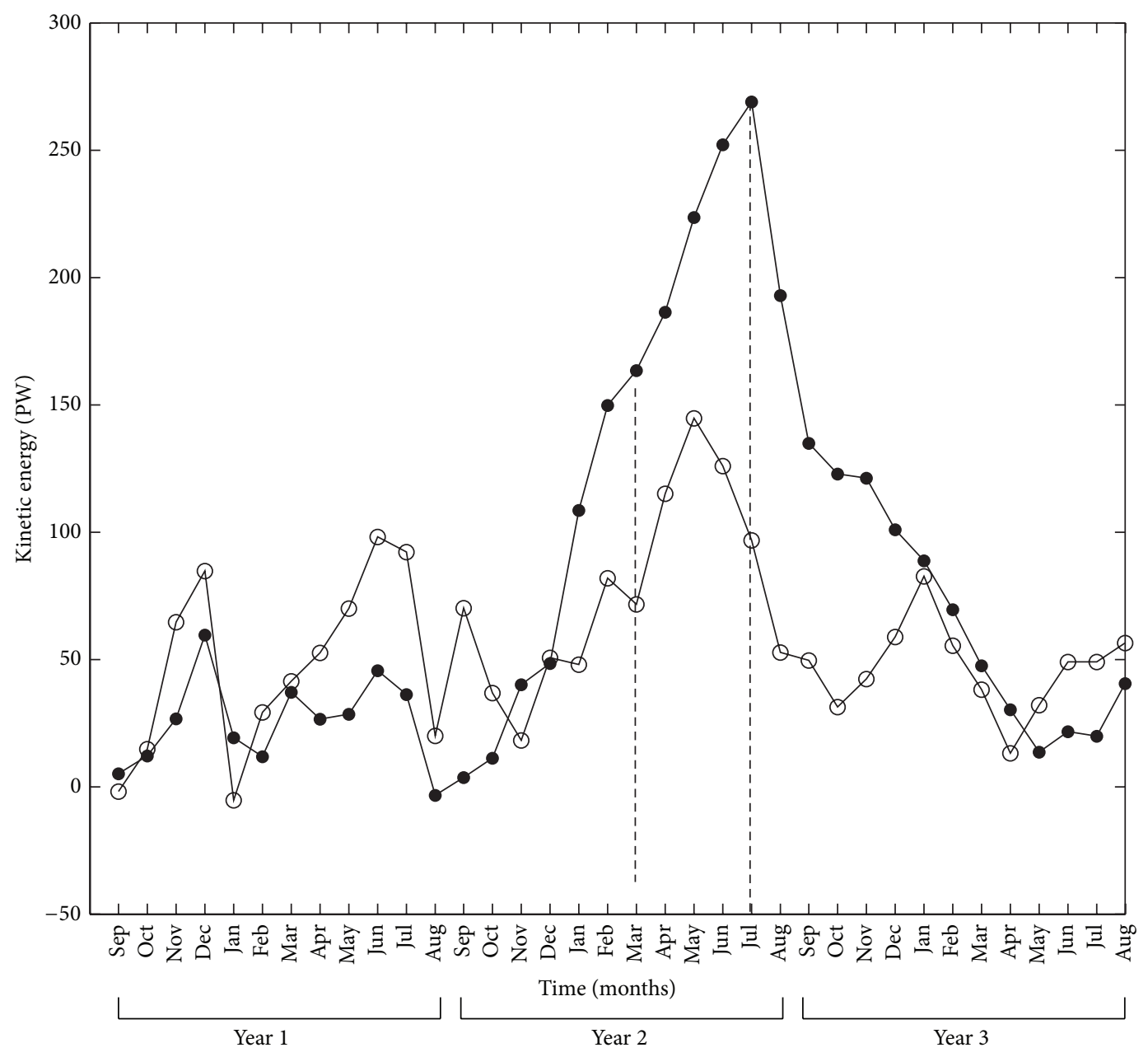

Figure 5: Global kinetic energy anomaly time series plot (filled circles for the ocean kinetic energy and empty circles for the global wind energy over the sea surface). The values of the work performed by the wind were multiplied by a factor of $10^{3}$ [13].

TABLE 2: Volume transports estimates obtained from hydrographic data sets in the monitored section latitudes. Adapted from da Silveira et al. [2].

\begin{tabular}{lccc}
\hline Latitude & $\begin{array}{c}\text { Reference level } \\
\text { (meters) }\end{array}$ & $\begin{array}{c}\text { Volume } \\
\text { transport (Sv) }\end{array}$ & Reference \\
\hline $23^{\circ}$ & 550 & $2.2 / 2.7$ & {$[26]$} \\
$23^{\circ}$ & $500-1300$ & 4.4 & {$[27]$} \\
$25^{\circ}$ & 750 & 7.3 & {$[28]$} \\
$28-30^{\circ}$ & $1550-1600$ & 11.4 & {$[29]$} \\
\hline
\end{tabular}

an absolute value of $-4.26 \mathrm{~Sv}$, with a standard deviation of \pm 0.16 . In Section 2, as in Section 1, it is possible to observe the strong influence of a southward flow in the upper layer transports. The annual mean ocean volume transport had values of $-5.74 \mathrm{~Sv}( \pm 0.15)$. In Section 3, the highest values of annual mean transports volumes into upper layers reached $-8.32 \mathrm{~Sv}( \pm 0.36)$. These values are close to the estimations obtained by others studies in neighboring regions presented by da Silveira et al. [2] (Table 2).
Although the comparisons between the ocean volume transport values obtained in this work and the values estimated from observed data found in the scientific literature are close, it is important to emphasize the differences between them. The vertical water column extensions used to estimate the transports in this work (Table 1) are shallower when compared to historical estimates based on observed data sets for near ocean regions (Table 2). This fact could explain the differences observed between the ocean volume transport estimates presented in both cited tables.

4.2. Perturbed Experiment. The imposition of an interannual perturbed global wind stress field generated interannual variability in the global ocean kinetic energy (OKE) cycle during the three simulated years. Figure 5 presents the time series of global OKE and wind stress anomaly energy for the entire period of the perturbed experiment. Only the imposition of an interannual ENSO-type global wind stress field was able to introduce significant global OKE anomalies. The second year presented the most energetic months, and the global ocean kinetic energy maximum peak occurred 


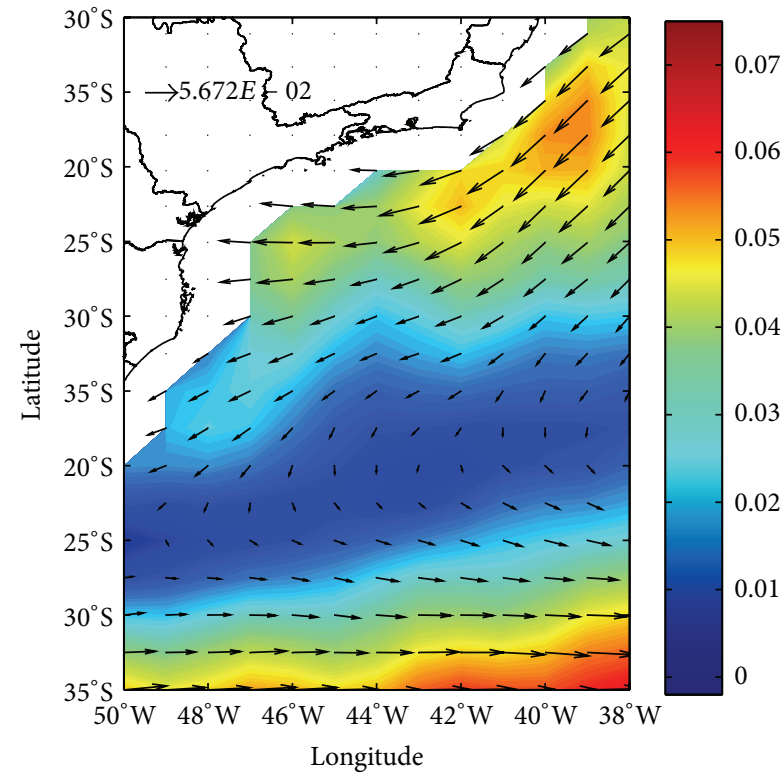

(a)

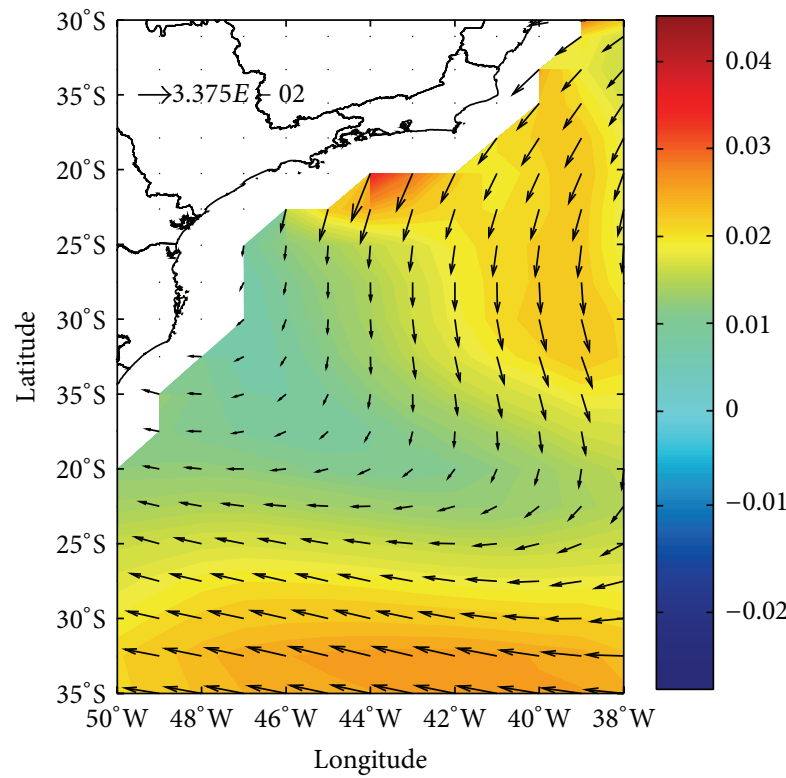

(c)

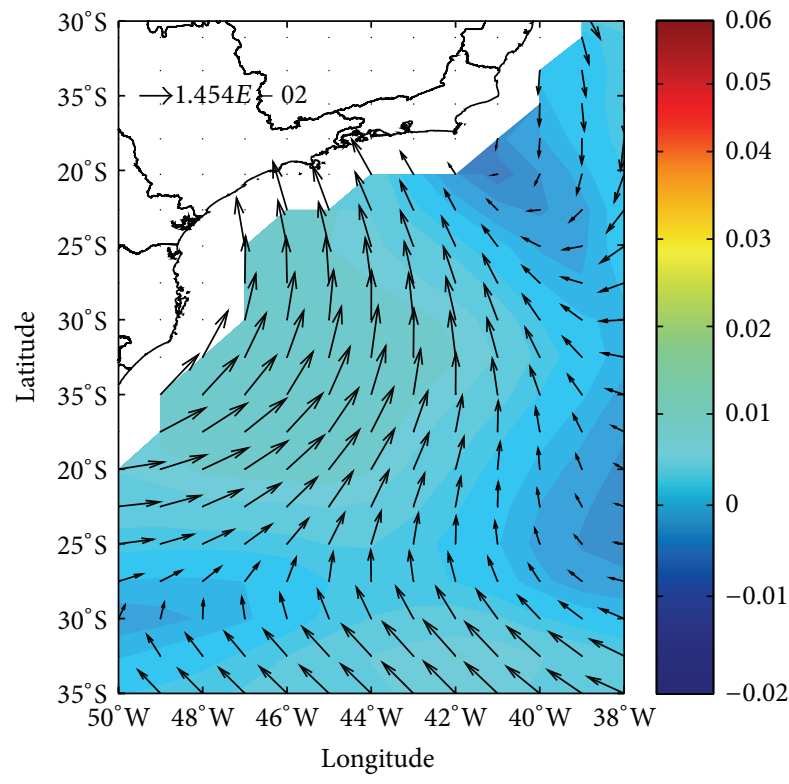

(b)

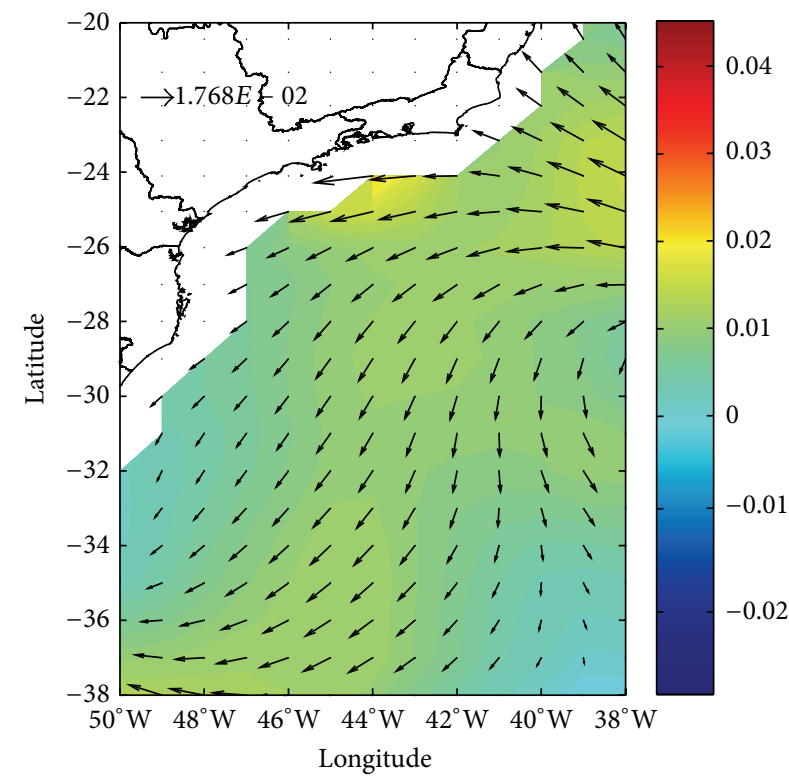

(d)

Figure 6: Annual mean wind stress vector field superimposed by the magnitude field for the climate experiment (a). Annual mean wind stress anomaly field superimposed by the wind stress difference vector field for year 1 (b), year 2 (c), and year 3 (d).

at the 23rd month of integration. The global ocean work performed by the wind stress field over the sea surface had an energy peak in the 21st month. This result suggests a time lag of approximately two months between the peaks in global wind energy that led to the global OKE (Figure 5).

The annual mean vertically integrated meridional volume transport values were estimated by each integrated perturbed year, being year 1 the first perturbed year, year 2 the second perturbed year and year 3 the third perturbed year. Interannual variations of BC meridional vertically integrated volume transport were observed in the three sections. Section 3 presented strongest variability with an increase of approximately $2 \mathrm{~Sv}$ from its climatological meridional volume transport value during the third perturbed year (Table 3 ). The three sections presented a weakening of the meridional volume transport during the first perturbed integrated year. This variability is apparently locally related to intensity variations of the South Atlantic atmospheric subtropical high (SASH). This fact can be inferred from the annual mean local anomaly wind stress fields shown in Figure 6 for each perturbed 


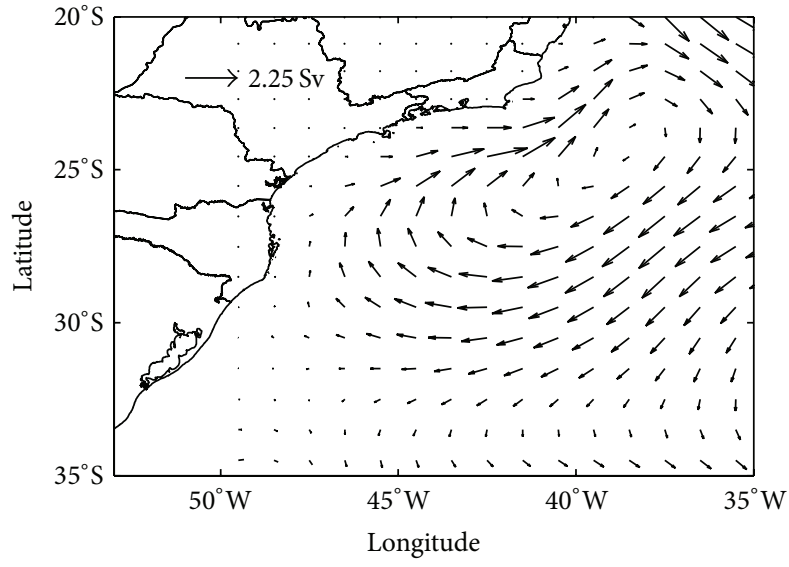

(a)

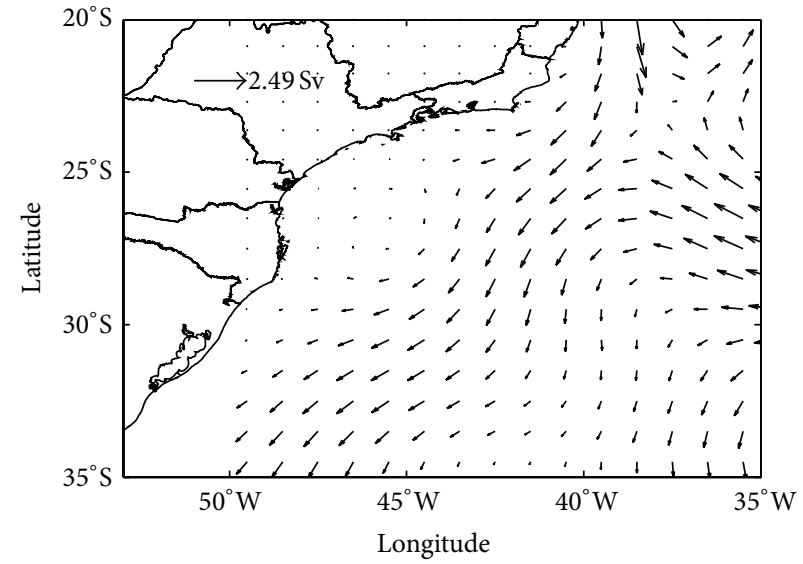

(b)

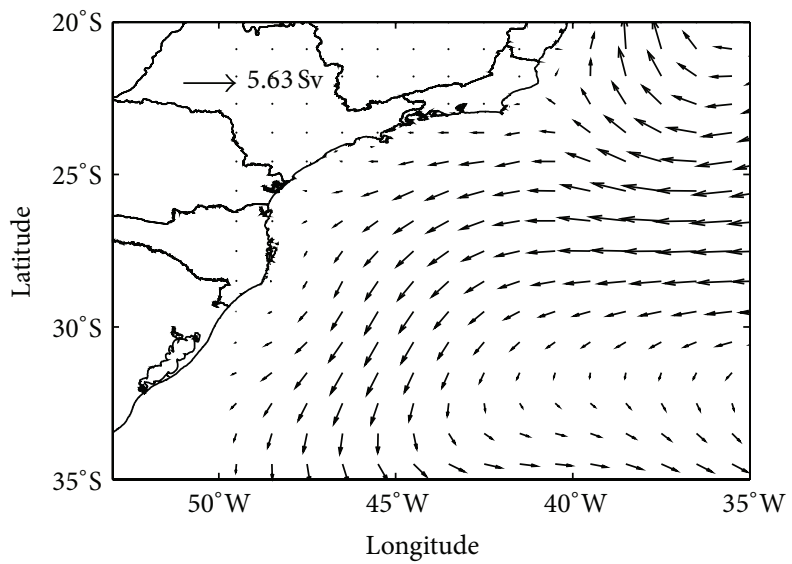

(c)

Figure 7: Annual mean integrated volume transport difference vector (units of Sv) field for 0-298.3 meters for the 3 perturbed years: year 1 (a), year 2 (b), and year 3 (c).

simulated year, which shows the weakening of the wind stress field during the first year and the strengthening of this property during the second and the third years of integration. In fact, the influence of local wind stress field over upper layer BC flux had already been identified by other works. Matano [30], studying the causes of the BC separation from the coast, concluded that when the MC flow is weak, the wind stress curl governs the upper layer dynamics of the BC flux.

In Figure 7, the first layer (0-298.3 m) annual mean difference vector of integrated volume transport for the three simulated years is shown. The upper layer volume transport decreases for the first year and the BC upper layer flux is enhanced for the next two simulated years in direct response to the imposition of the interannual global wind stress field. The last two years presented the most intense BC volume transport in Sections 2 and 3. In the final year, it is possible to observe a decrease in the southward BC flux near Section 1.

The intermediate (298.3-335.7 m) level of integrated volume transport difference vector field showed a behavior similar to that observed in the upper level, with a strong decrease in the southward transport between $25^{\circ} \mathrm{S}$ and $30^{\circ} \mathrm{S}$ for the first perturbed year. During this period, the model also represented significant changes in the bifurcation zone near $23^{\circ} \mathrm{S}$ with a decreasing of the southward BC flow over higher latitudes and also a decrease in the northward intermediate flow over lower latitudes. The second and third years showed a return to the climate circulation behavior with an increasing in the southward volume transport, below $23^{\circ} \mathrm{S}$, associated with the southward $\mathrm{BC}$ flow and also in the northward flow above $23^{\circ} \mathrm{S}$ in lower latitudes.

The volume transports in the lower monitored level (335.7 m-524.2 m), similarly to the other layers, presented significant interannual variability associated with the imposition of the perturbed wind field. The volume transport difference vector field showed a decrease in the northward flow over $23^{\circ} \mathrm{S}$ and lower latitudes in the first and second year with an enhancement of this transport during the third year. The bifurcation zone that, on the climate experiment, is centered in $28^{\circ} \mathrm{S}$ was slightly moved to the north in the third year, which also presents an intensification of the southward volume transport over $30^{\circ} \mathrm{S}$ and higher latitudes.

Figure 8 shows the annual mean meridional volume transport anomaly vertical distribution over the three sections for year 1 . Positive values of the meridional velocity are 


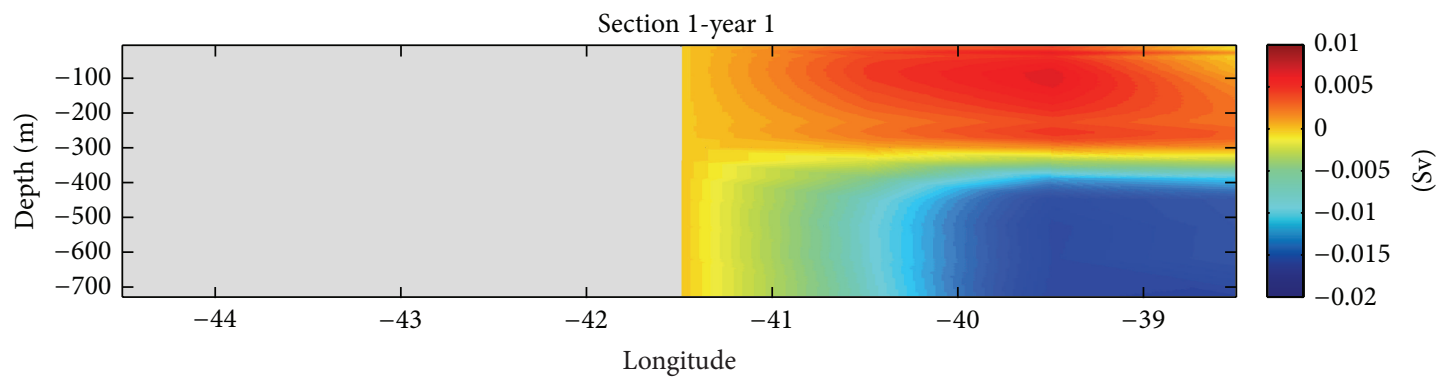

(a)

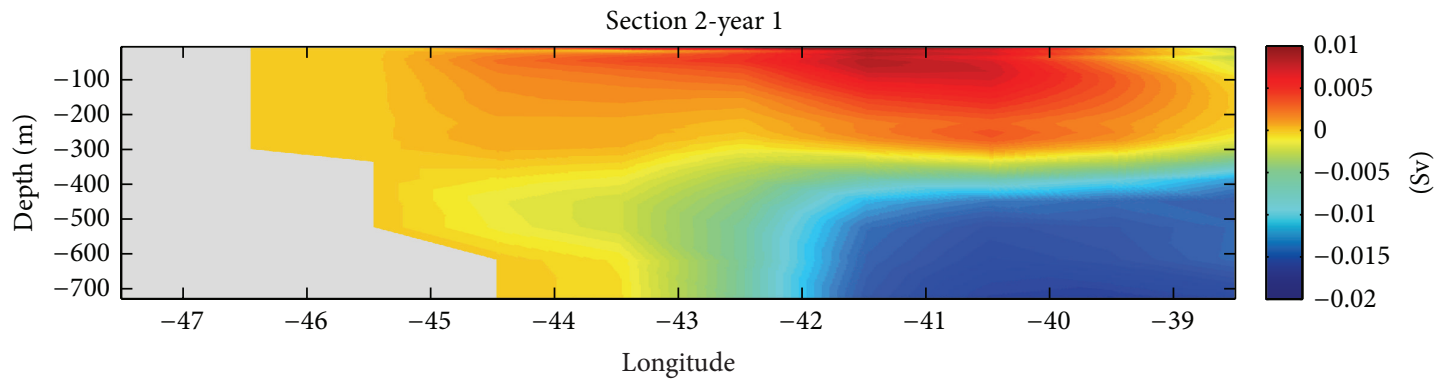

(b)

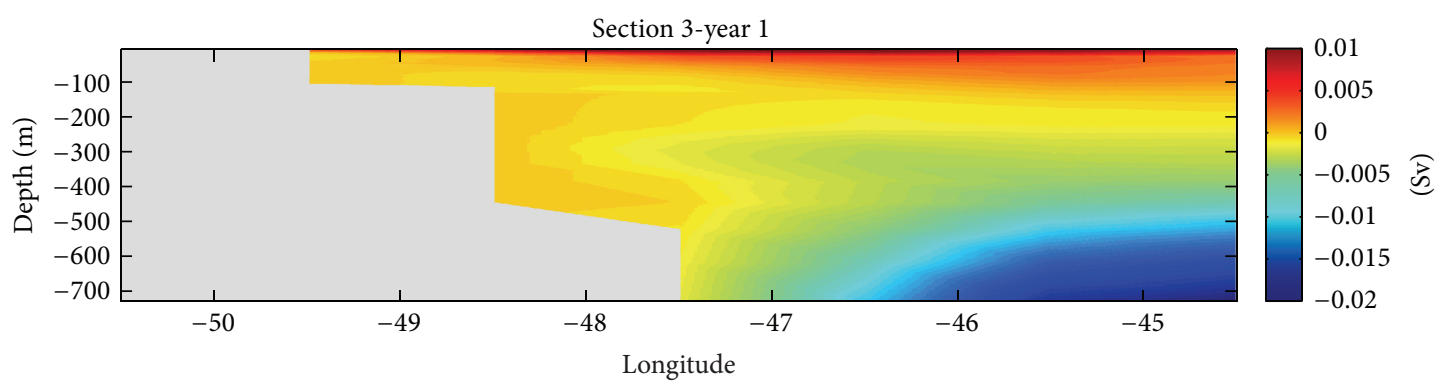

(c)

FIGURE 8: First perturbed integration year annual mean meridional volume transport anomaly field (units of Sv) for Sections 1 (a), 2 (b), and 3 (c). Sections are showed in Figure 1.

TABLE 3: Annual mean (and the standard deviation) volume transport values for each monitored section in the climate experiment and for the three perturbed simulated years.

\begin{tabular}{lcccc}
\hline Sections & Climate & Perturbed year $(1)$ & Perturbed year $(2)$ & Perturbed year $(3)$ \\
\hline Section 1 & $-4.26( \pm 0.16)$ & $-3.86( \pm 0.68)$ & $-4.63( \pm 0.76)$ & $-3.82( \pm 0.44)$ \\
Section 2 & $-5.74( \pm 0.15)$ & $-5.27( \pm 0.97)$ & $-6.345( \pm 0.89)$ & $-6.08( \pm 0.75)$ \\
Section 3 & $-8.32( \pm 0.36)$ & $-8.27( \pm 0.52)$ & $-8.81( \pm 1.51)$ & $-10.29( \pm 0.59)$ \\
\hline
\end{tabular}

observed in the first 100 meters of all three sections. These positive values indicate a decrease in the southward flow associated with the BC. Section 3 presents annual mean negative anomaly values in depths below 300 meters, indicating an increase in the southward flow that was already observed in Figure 9. Section 1 presented meridional volume transport negative anomaly values for depths below 300 meters, which is associated with a northward volume transport decrease in this region for the first perturbed integration year.

Section 3 presented an increase in the climate southward flow observed in Figure 2 by the presence of a negative anomaly meridional velocity component in the entire water column. These positive anomaly meridional volume transport values are stronger predominantly below 400 meters in the third perturbed year.

Table 3 shows the annual mean values (and the associated standard deviation) of meridional volume transport vertically integrated along the three zonal sections for the climate and the perturbed experiments. The analysis of these values reveals common characteristics for the three sections, such as the volume transport decreasing over the first perturbed year and a relative increase over the second integration year. Section 2 showed an enhancement of the annual mean volume transport for the last two perturbed years. In the 


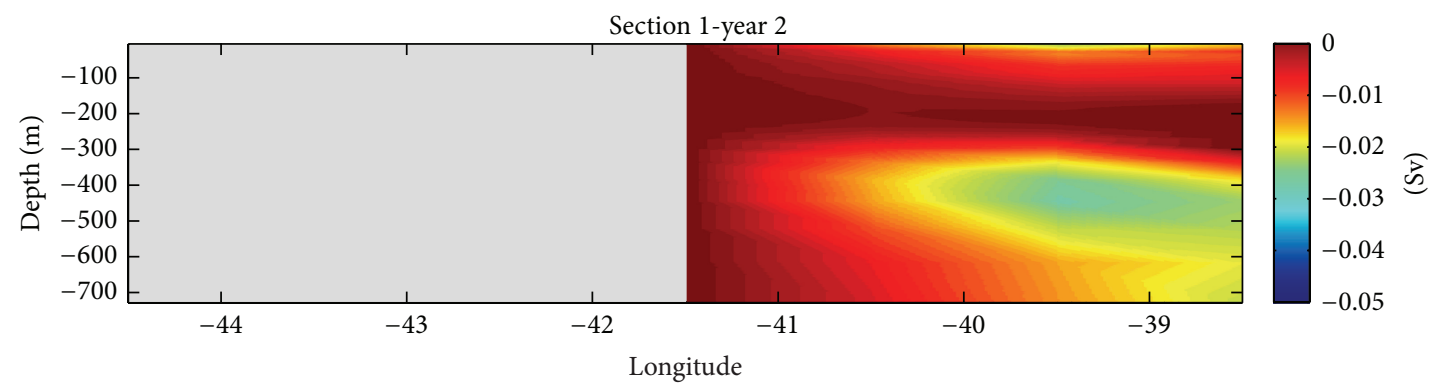

(a)

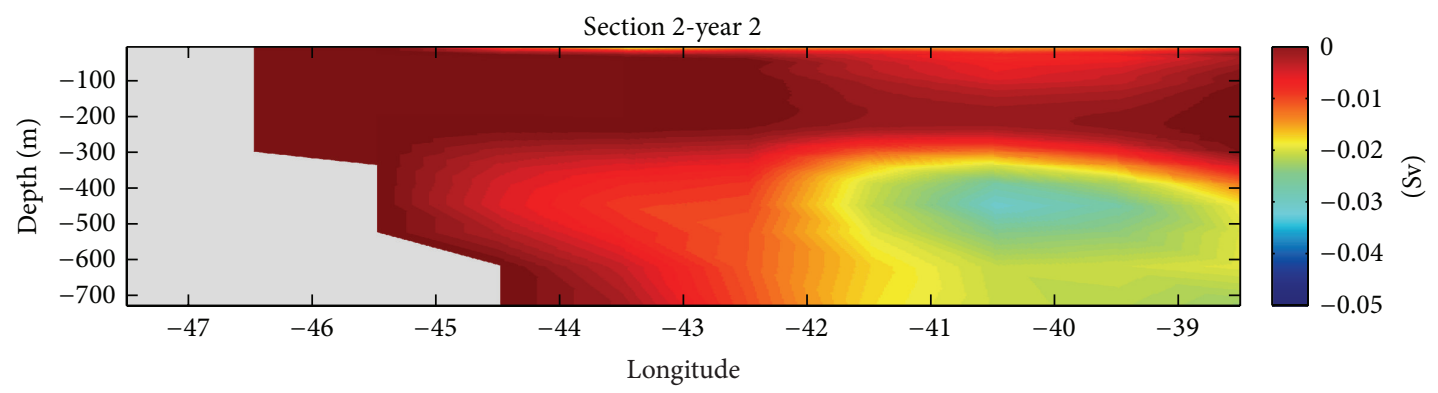

(b)

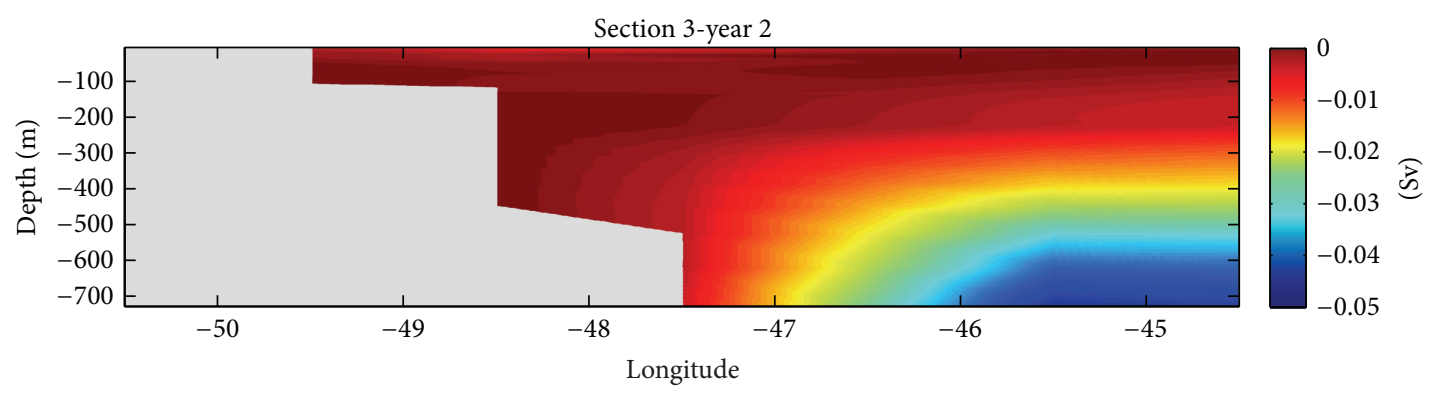

(c)

FIGURE 9: Second perturbed integration year annual mean meridional volume transport anomaly field (units of Sv) for Sections 1 (a), 2 (b), and 3 (c). Sections are showed in Figure 1.

first year, the volume transport values decreased. Section 3 showed an enhancement of the annual mean volume transport for the third perturbed year that also presented the highest volume transport value. In fact, in Section 3, the southward anomaly volume transport vector field at this latitude contributed to the southward enhancement over all of the layers.

Monthly mean meridional volume transport vertically integrated fluctuations were analyzed in the ocean layer between the surface and 524.2 meters. Sections 1 and 2 are in good agreement with the local wind modulation. During the second perturbed integration year, an intensification of the annual mean northeast wind fields was observed, as a consequence, accelerated the integrated volume transport field obtained for Sections 1 and 2 (Figure 9). These two sections presented the most intense monthly mean volume transport values in July of the second integration year, which was also when the global OKE peak occurred (Figure 5). Section 1 presents less intense values that are related to its shallower southward transport configuration and with a northward transport presence below it. Section 3 presents the most intense southward volume transports for the three perturbed simulated years (Figure 10). This intensity may be related to its deeper southward transport configuration and the contributions of an anticyclonic circulation cell transport that flows in this level and bifurcates near $30^{\circ} \mathrm{S}$ (Figure 3 ). The most intense monthly mean integrated volume transport value for this section is observed in November of the third perturbed simulated year, just four months after Sections 1 and 2 reach their maxima (Figure 11). This result indicates that the ocean volume transports in the studied region have different response time scales to the local surface wind field. This fact could be related to the interaction in deeper layers with termohaline oceanic transports fluctuations that are not directly influenced by the interannual variability of the local SBB wind and have more importance in feeding the southward volume transport field associated with BC in higher latitudes.

\section{Discussion}

This work identifies and quantifies the occurrence of significant interannual variability in the $\mathrm{BC}$ volume transport 


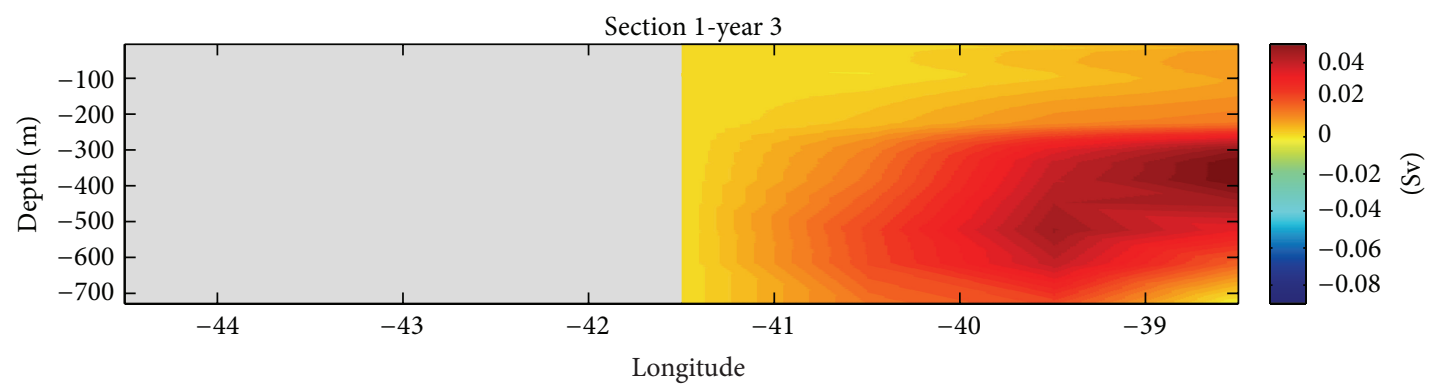

(a)

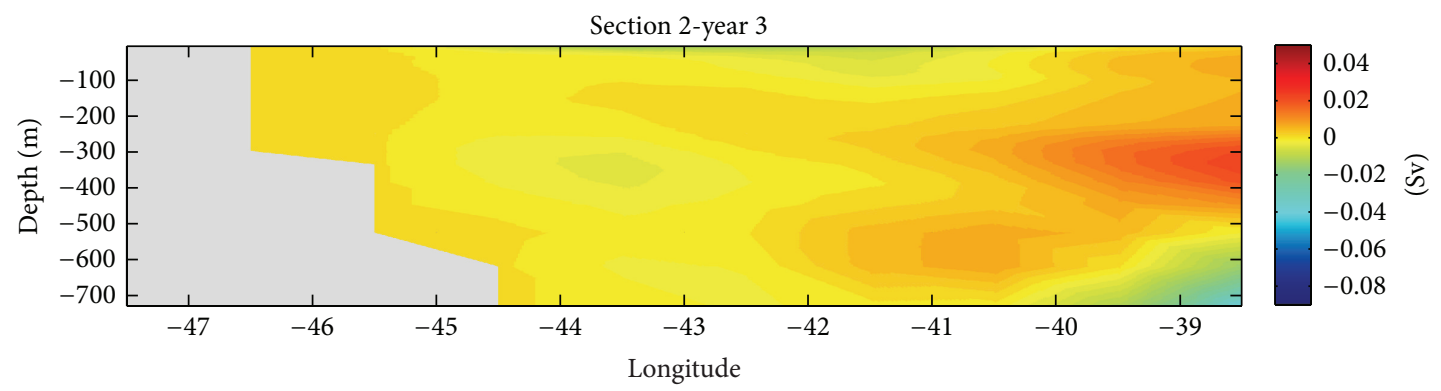

(b)

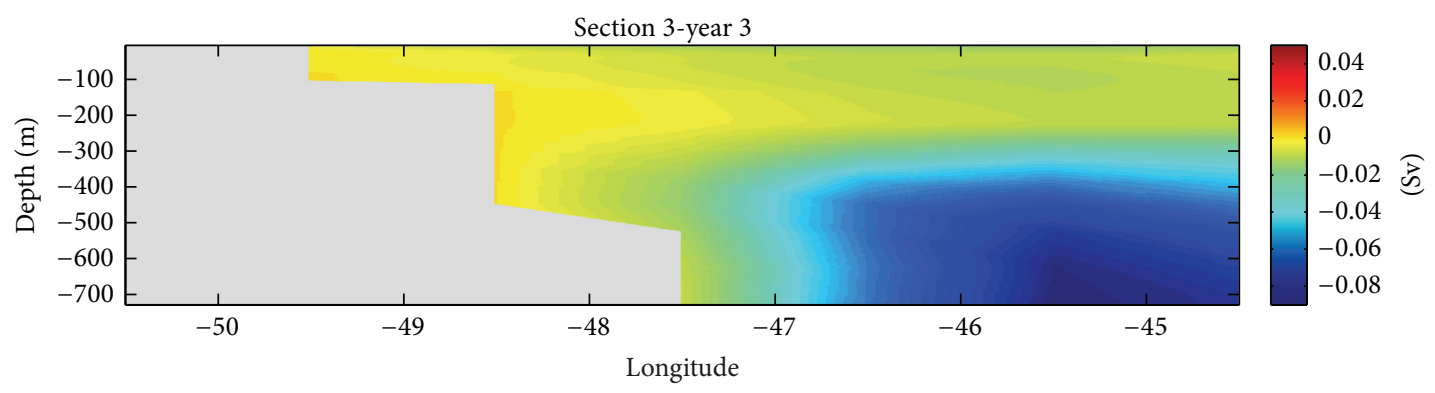

(c)

FIGURE 10: Third perturbed integration year annual mean meridional volume transport anomaly field (units of Sv) for Sections 1 (a), 2 (b), and 3 (c). Sections are showed in Figure 1.

during the three simulated years. In spite of its coarse resolution, the model is capable of representing Sverdrupstyle response to large-scale wind stress curl changes. When considering the studies on climate the low frequency flow can supply significant information on the impact of heat distribution in the ocean thus contributing to future studies on its influence on the climate over near continental areas. However, the coarse horizontal resolution of the grid $\left(1^{\circ}\right.$ latitude $\times 1^{\circ}$ longitude) in the studied region could also influence the results obtained. In fact, a significant portion of coastal volume transport values and eddy flow interactions are not represented in this model grid configuration and consequently are not considered in transports estimates. This fact may contribute to the low intensity of the volume transports. It is also important to note that the thickness of $\mathrm{BC}$ flow presented for the three sections was always shallower than the scientific literature observed values over neighboring regions $[1,2]$. This fact could be related also to the monthly frequency of the velocity field that would underestimate the volume transport values. The short time of model integration for the perturbed experiment could underestimate the observed interannual variability in the SBB region, particularly those related to the $\mathrm{BC}$ flux. This fact can be more clearly observed in the OKE anomaly data in the SBB and near offshore region delimited area $\left(60^{\circ} \mathrm{W}-\right.$ $30^{\circ} \mathrm{W}$ and $20^{\circ} \mathrm{S}-30^{\circ} \mathrm{S}$ ) integrated for the first 650 meters (Figure 12). The behavior of this curve is different from the global integrated OKE (Figure 5). The time series analysis revealed that for $\mathrm{SBB}$ region, the $\mathrm{OKE}$ is increasing even in the third perturbed integration year, when the highest integrated anomaly energy values occurred. This result suggests a direct association with the wind stress decrease observed during the first perturbed integrated year when negative OKE anomaly values were observed (Figure 6). During the second and especially in the third perturbed integrated year, the SBB local southward meridional wind stress component increased, and as a consequence, it is possible to observe the occurrence of positive anomaly OKE values in the SBB region.

The remote or local (South Atlantic basin) windgenerated oceanic processes could also be affecting the SBB 


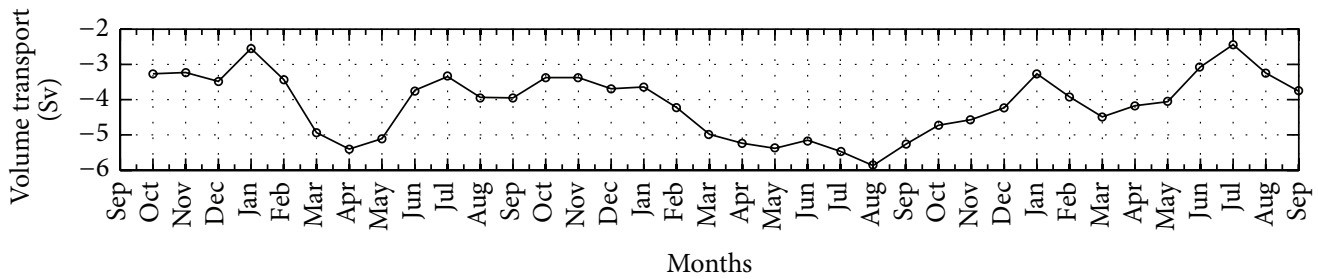

(a)

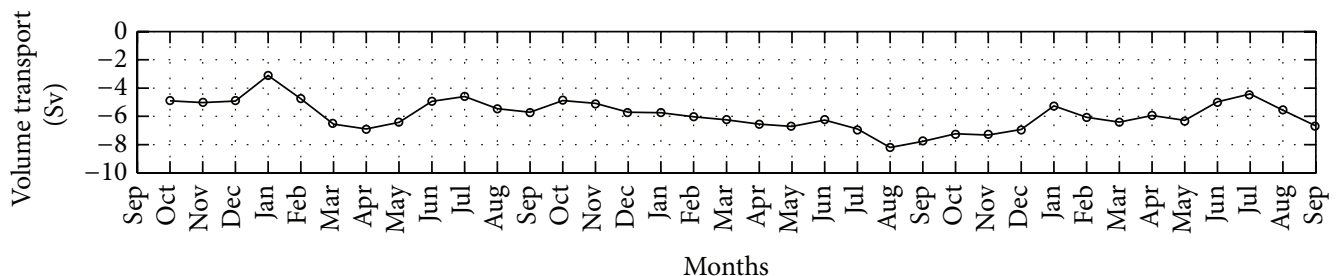

(b)
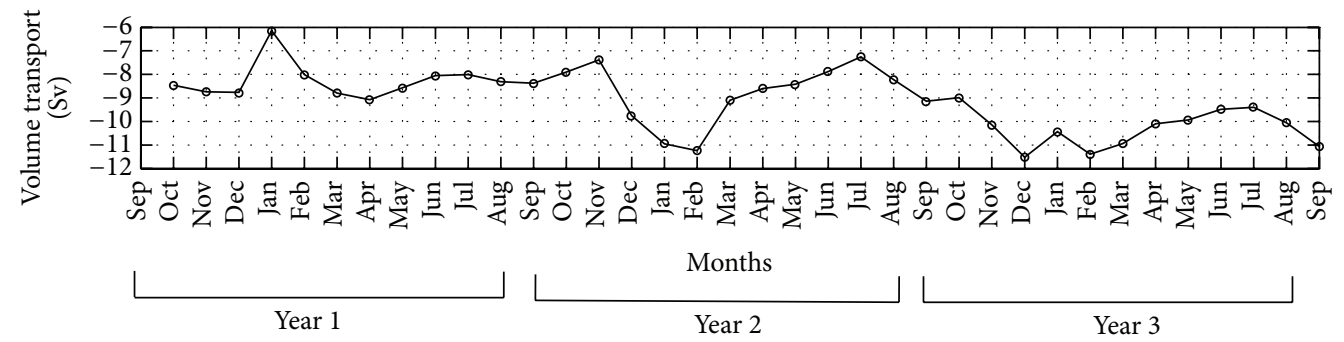

(c)

FIGURE 11: Time series plot of perturbed monthly mean meridional volume transport vertically integrated for Sections 1 (a), 2 (b), and 3 (c).
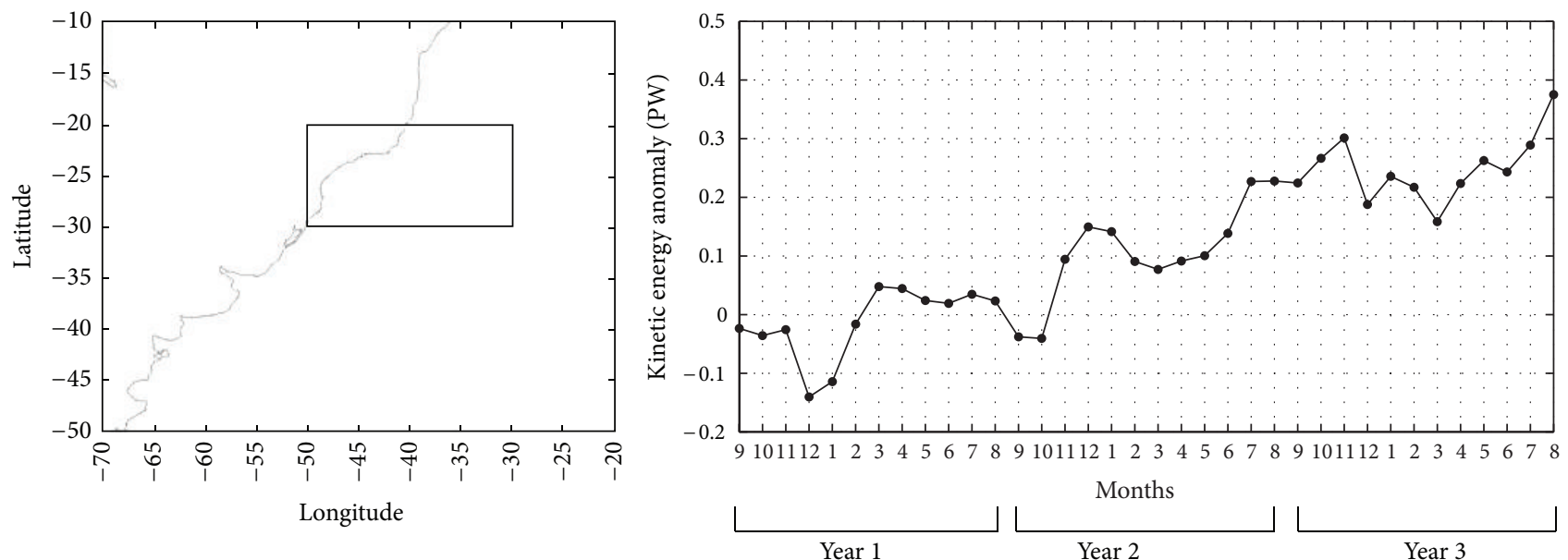

FIGURE 12: Regional SBB OKE anomaly time series plot. The OKE values are integrated for the first 650 meters.

volume transport three-dimensional field. One way to better investigate the time evolution of the SBB OKE time distribution would be to increase the time of the model integration, restoring the global wind stress conditions that were used in the control experiment. This methodology would also be useful to identify the influence of different potential ocean variability modes over the studied region generated by the global ENSO-type wind stress field, such as Rossby, Kelvin or continental shelf waves that would be remotely generated.
These waves would disturb the density fields distributions and consequently affect the ocean volume transports. Vivier et al. [10], based on observed data, suggested that Kelvin waves originating from the Equatorial Pacific and propagating along the west coast of South America would contour the continent, reaching the South Atlantic basin until $40^{\circ} \mathrm{S}$.

The interannual variability of the meridional volume transports zero-motion levels that were used to estimate the vertical extension of each section are presented in Figure 13. 


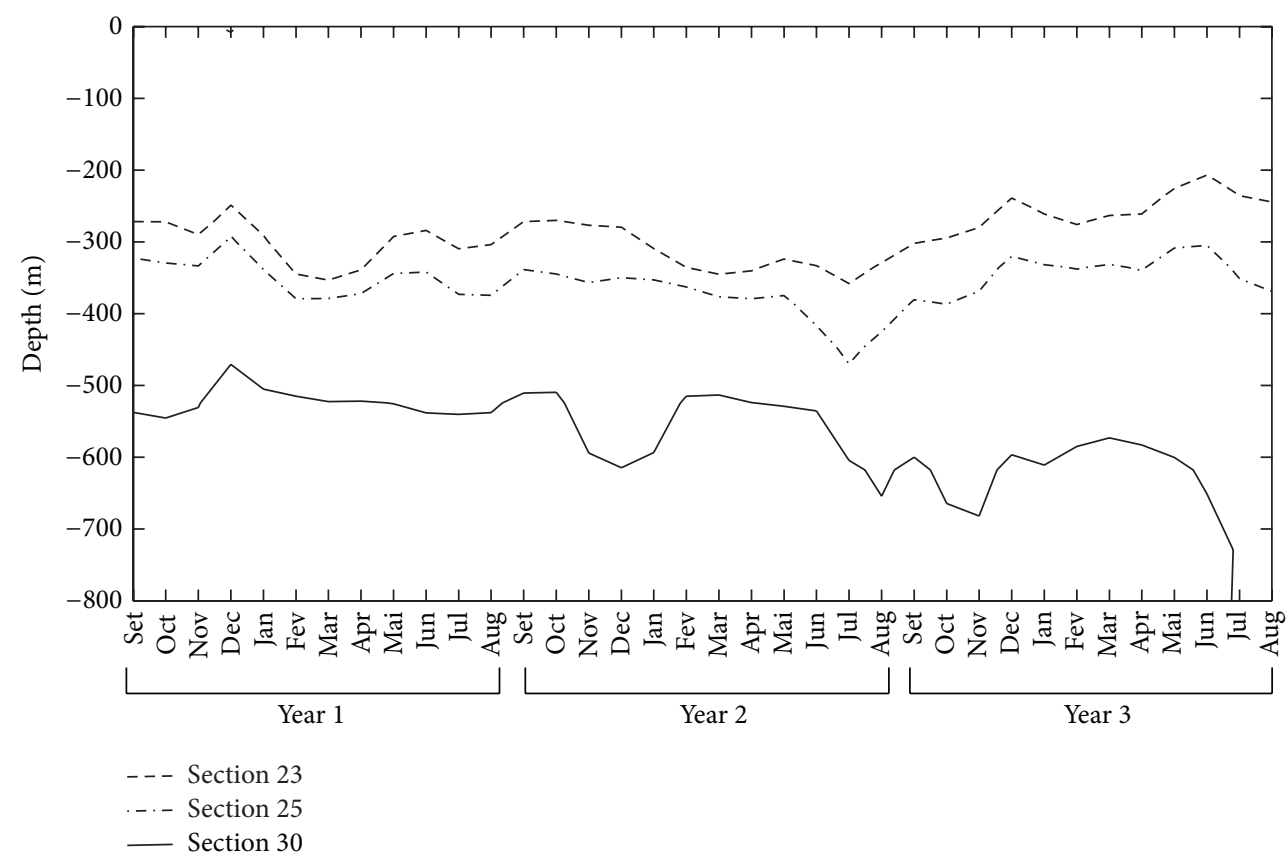

FiguRE 13: Meridional volume transport zero-motion level time series plot for the three integrated years and zonal averaged for each monitored section.

It is possible to find significant change in these levels for each section. Sections 1 and 2 presented a similar behavior, becoming deeper during the end of the second integration year and shallower in the end of the third integration year. Section 3 presented a continuously deepening process during the entire perturbed experiment. Although significant nomotion level changes were observed in the three section, it is important to note that even for Sections 1 and 2, these changes were very small compared with Section 3 . Section 3 presented the most significant changes, which occurred predominantly at the end of the third integration year.

\section{Conclusions}

The imposition of an ENSO-type global monthly mean wind stress field in an OGCM revealed important interannual variability fluctuations in the tridimensional interannual volume transport fields over the SBB and near offshore region. Interannual and annual fluctuations over the ocean volume transports in the studied region are mainly detected over the region where the $\mathrm{BC}$ flux is located. The $\mathrm{BC}$ upper and medium layer volume transports present a decrease in their intensity during the first year, while an increase is observed for the last two integrated perturbed years. The deep layer ocean volume transport exhibited a continuous intensification process, which indicates a minor direct dependence of this layer to the local wind stress field and possibly indicates a dominance of remote ocean process influences.

It was also possible to observe a small time lag between the integrated volume transports changes in each section during the climate and perturbed experiment. Integrated volume transport time series indicate that Sections 1 and 2 are almost in phase with the occurrence of the most intense southward volume transport that occurred in July of the second perturbed integrated year. Volume transport over Section 3 presented its most intense value just in November of the third perturbed year (four months after Sections 1 and 2).

This work contributed to the knowledge of seasonality and interannual variability of $\mathrm{BC}$ system volume transport field associated with changes in the global wind stress field. It was concluded that an anomalous ENSO type global wind stress field could affect locally the BC velocity field and significantly alter its seasonal dynamic behavior. These results would contribute to the understanding of some ocean properties variability over SBB such as temperature field.

\section{Conflict of Interests}

The authors declare that there is no conflict of interests regarding the publication of this paper.

\section{References}

[1] R. G. Peterson and L. Stramma, "Upper-level circulation in the South Atlantic Ocean," Progress in Oceanography, vol. 26, no. 1, pp. 1-73, 1991.

[2] I. C. A. da Silveira, A. C. K. Schmidt, E. J. D. Campos, S. S. de Godoi, and Y. Ikeda, "A corrente do Brasil ao largo da costa leste brasileira," Revista Brasileira de Oceanografia, vol. 48, no. 2, pp. 171-183, 2000.

[3] F. A. Schott, M. Dengler, R. Zantopp, L. Stramma, J. Fischer, and P. Brandt, "The shallow and deep Western boundary circulation of the South Atlantic at $5^{\circ}-11^{\circ}$ S," Journal of Physical Oceanography, vol. 35, no. 11, pp. 2031-2053, 2005. 
[4] L. Stramma, M. Rhein, P. Brandt, M. Dengler, C. Böning, and M. Walter, "Upper ocean circulation in the Western Tropical Atlantic in boreal fall 2000," Deep Sea Research Part I: Oceanographic Research Papers, vol. 52, no. 2, pp. 221-240, 2005.

[5] R. Lumpkin and S. Garzoli, "Interannual to decadal changes in the western South Atlantic's surface circulation," Journal of Geophysical Research C: Oceans, vol. 116, no. 1, Article ID C01014, 2011.

[6] D. R. A. Veleda, M. Araujo, M. Silva, and R. Montagne, "Seasonal and interannual variability of the southern south equatorial current bifurcation and meridional transport along the eastern Brazilian edge," Tropical Oceanography, vol. 39, no. 1, pp. 27-59, 2011.

[7] G. J. Goni, F. Bringas, and P. N. Dinezio, "Observed low frequency variability of the Brazil Current front," Journal of Geophysical Research C: Oceans, vol. 116, no. 10, Article ID C007198, 2011.

[8] M. Cataldi, L. P. F. Assad, A. R. Torres Júnior, and J. L. D. Alves, "Estudo da influência das anomalias da TSM do Atlântico Sul extratropical na região da Confluência Brasil-Malvinas no regime hidrometeorológico de verão do Sul e Sudeste do Brasil," Revista Brasileira de Meteorologia, vol. 25, no. 4, pp. 513-524, 2010.

[9] M. A. Alexander, I. Bladé, M. Newman, J. R. Lanzante, N.-C. Lau, and J. D. Scott, "The atmospheric bridge: The influence of ENSO teleconnections on air-sea interaction over the global oceans," Journal of Climate, vol. 15, no. 16, pp. 2205-2231, 2002.

[10] F. Vivier, C. Provost, and M. P. Meredith, "Remote and local forcing in the Brazil-Malvinas region," Journal of Physical Oceanography, vol. 31, no. 4, pp. 892-913, 2001.

[11] C. A. D. Lentini, G. G. Podestá, E. J. D. Campos, and D. B. Olson, "Sea surface temperature anomalies on the western south atlantic from 1982 to 1994," Continental Shelf Research, vol. 21, no. 1, pp. 89-112, 2001.

[12] A. R. Torres Jr., Estudo numérico sobre tele-conexão atmosférica entre fenômenos oceânicos do Pacífico Equatorial e do Atlântico Sul [Ph.D. thesis], Federal University of Rio de Janeiro, 2005.

[13] L. P. F. Assad, A. R. Torres Jr., R. N. Candella, and A. S. Mascarenhas Jr., "Brazil-Malvinas Confluence upper ocean temperature anomalies induced by an ENSO wind forcing," Ciencias Marinas, vol. 36, no. 3, pp. 267-284, 2010.

[14] B. M. Castro and L. B. Miranda, "Physical oceanography of the Western Atlantic continental shelf located between $4 \mathrm{~N}$ and 34 S," in The Sea, A. R. Robinson and K. H. Brink, Eds., vol. 11, pp. 209-251, John Wiley \& Sons, New York, NY, USA, 1998.

[15] R. G. Soutelino, I. C. A. da Silveir, A. Gangopadhyay, and J. A. Miranda, "Is the Brazil current eddy-dominated to the North of $20^{\circ}$ S?" Geophysical Research Letters, vol. 38, no. 3, Article ID L03607, 2011.

[16] I. C. A. Silveira and L. B. Miranda, "On the origins of the North Brazil Current," Journal of Geophysical Research, vol. 99, no. 11, pp. 22501-22512, 1994.

[17] L. B. Miranda and B. M. Castro, "Geostrophic flow conditions of the Brazil Current at $19^{\circ}$ S," Ciencia Interamericana, vol. 22, pp. 44-48, 1982.

[18] L. Stramma and M. England, "On the water masses and mean circulation of the South Atlantic Ocean," Journal of Geophysical Research C: Oceans, vol. 104, no. 9, pp. 20863-20883, 1999.

[19] R. C. Pacanowsky and S. M. Griffies, The MOM3 Manual, Geophysical Fluid Dynamics Laboratory/NOAA, Princeton, NJ, USA, 1999.
[20] L. P. F. Assad, A. R. Torres Júnior, W. A. Zumpichiatti, A. S. Mascarenhas Júnior, and L. Landau, "Volume and heat transports in the world oceans from an ocean general circulation model," Brazilian Journal of Geophysics, vol. 27, no. 2, pp. 181-194, 2009.

[21] F. Röeske, "An atlas of surface fluxes based on the ECMWF reanalysis-a climatological dataset to force global ocean general circulation models," Tech. Rep. 323, Max-Planck Institut für Meteorologie, Hamburg, Germany, 2001.

[22] C. Sun, M. M. Rienecker, A. Rosati et al., "Comparison and sensitivity of ODASI ocean analyses in the Tropical Pacific," Monthly Weather Review, vol. 135, no. 6, pp. 2242-2264, 2007.

[23] L. P. de Freitas Assad, "ENSO-type wind stress field influence over global ocean volume and heat transports," in Climate Variability-Some Aspects, Challenges and Prospects, Abdel Hannachi, Ed., pp. 99-120, InTech, Rijeka, Croatia, 2011.

[24] E. M. Rasmusson and J. M. Wallace, "Meteorological aspects of the El Niño/Southern oscillation," Science, vol. 222, no. 4629, pp. 1195-1202, 1983.

[25] R. R. Rodrigues, L. M. Rothstein, and M. Wimbush, "Seasonal variability of the south equatorial current bifurcation in the atlantic ocean: a numerical study," Journal of Physical Oceanography, vol. 37, no. 1, pp. 16-30, 2007.

[26] L. B. de Miranda and B. M. Castro, "Condições do movimento geostrófico das águas adjacentes a Cabo Frio (RJ)," Boletim do Instituto Oceanográfico, vol. 28, no. 2, pp. 79-93, 1979.

[27] S. R. Signorini, "On the circulation and the volume transport of the Brazil Current between the Cape of São Tomé and Guanabara Bay," Deep-Sea Research, vol. 25, no. 5, pp. 481-490, 1978.

[28] E. J. D. Campos, J. E. Goncalves, and Y. Ikeda, "Water mass characteristics and geostrophic circulation in the South Brazil Bight: summer of 1991," Journal of Geophysical Research, vol. 100, no. 9, pp. 18537-18550, 1995.

[29] A. Fisher, The circulation and stratification of the Brazil Current [Dissertation], New York University, New York, NY, USA, 1964.

[30] R. P. Matano, "On the separation of the Brazil Current from the coast," Journal of Physical Oceanography, vol. 23, no. 1, pp. 7990, 1993. 

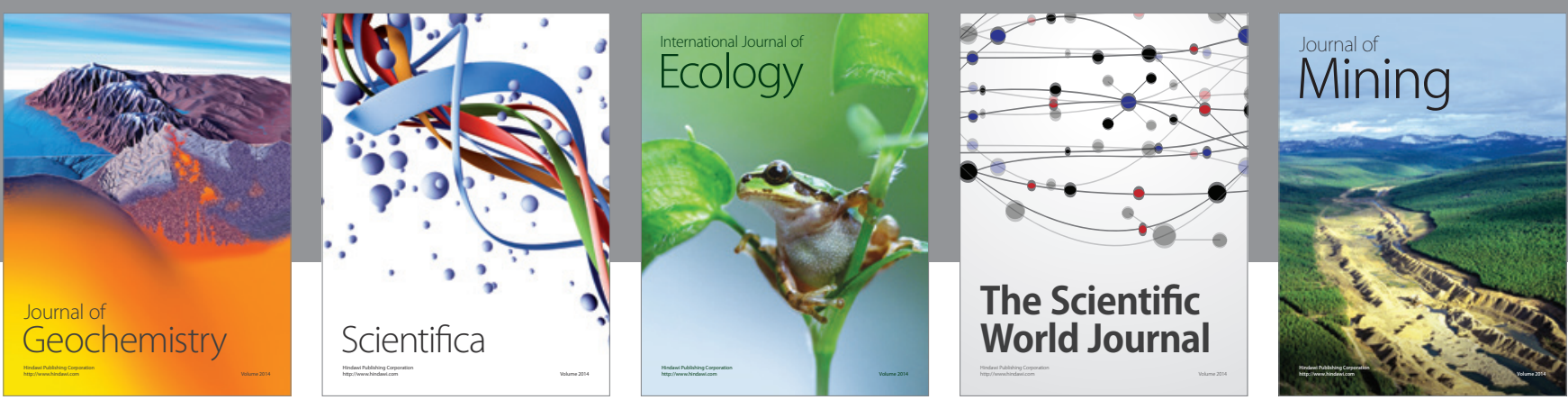

The Scientific World Journal
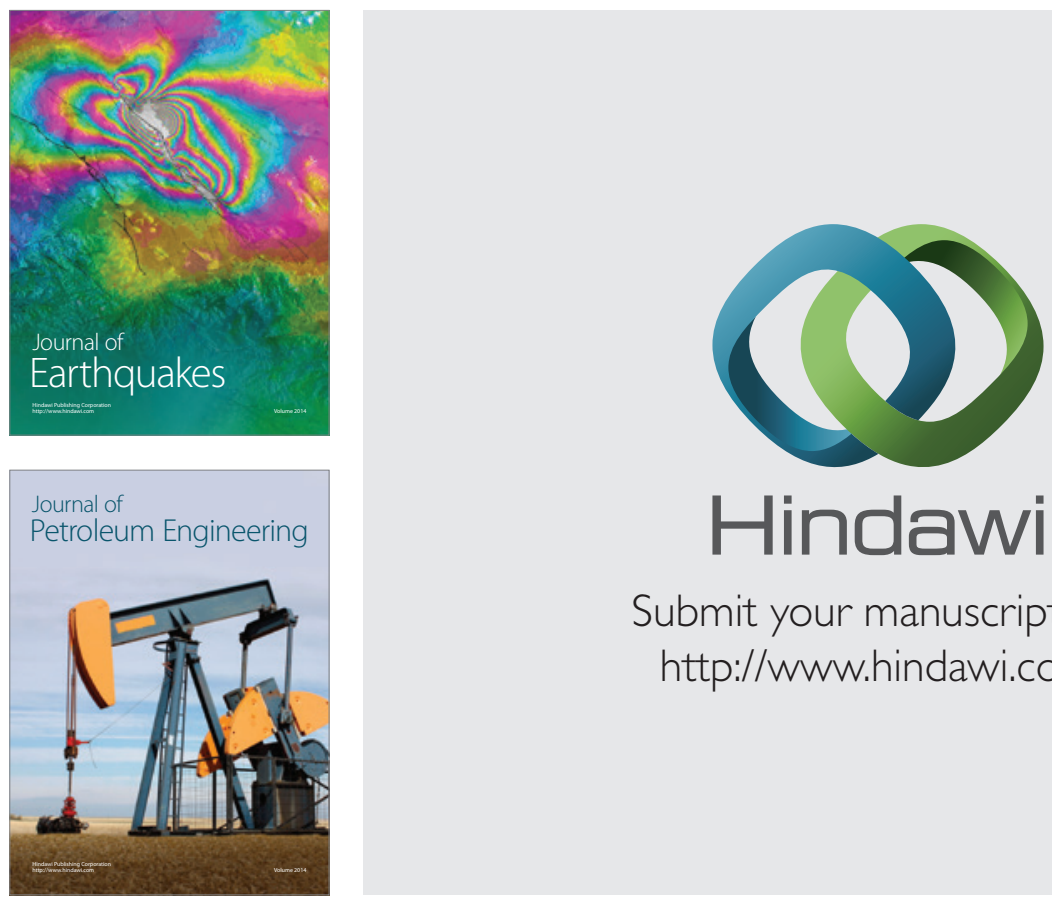

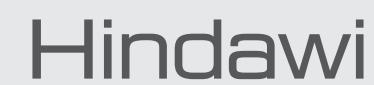

Submit your manuscripts at

http://www.hindawi.com
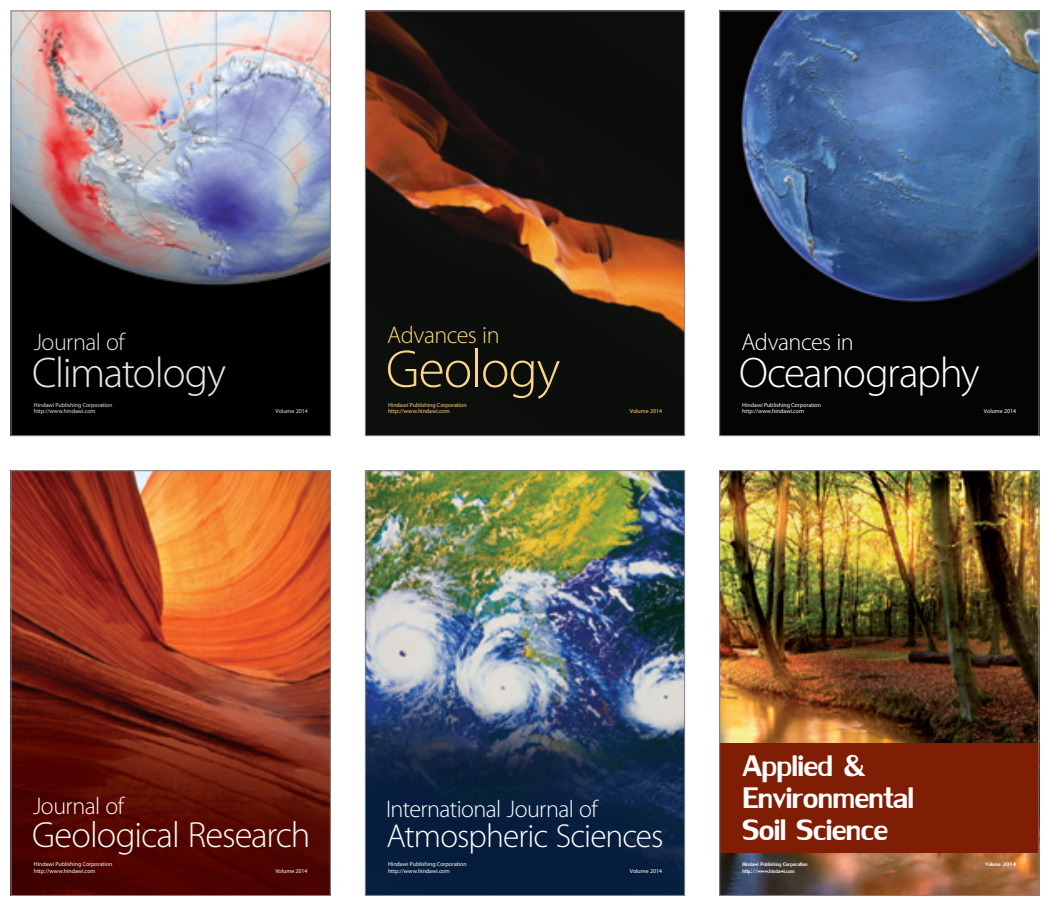
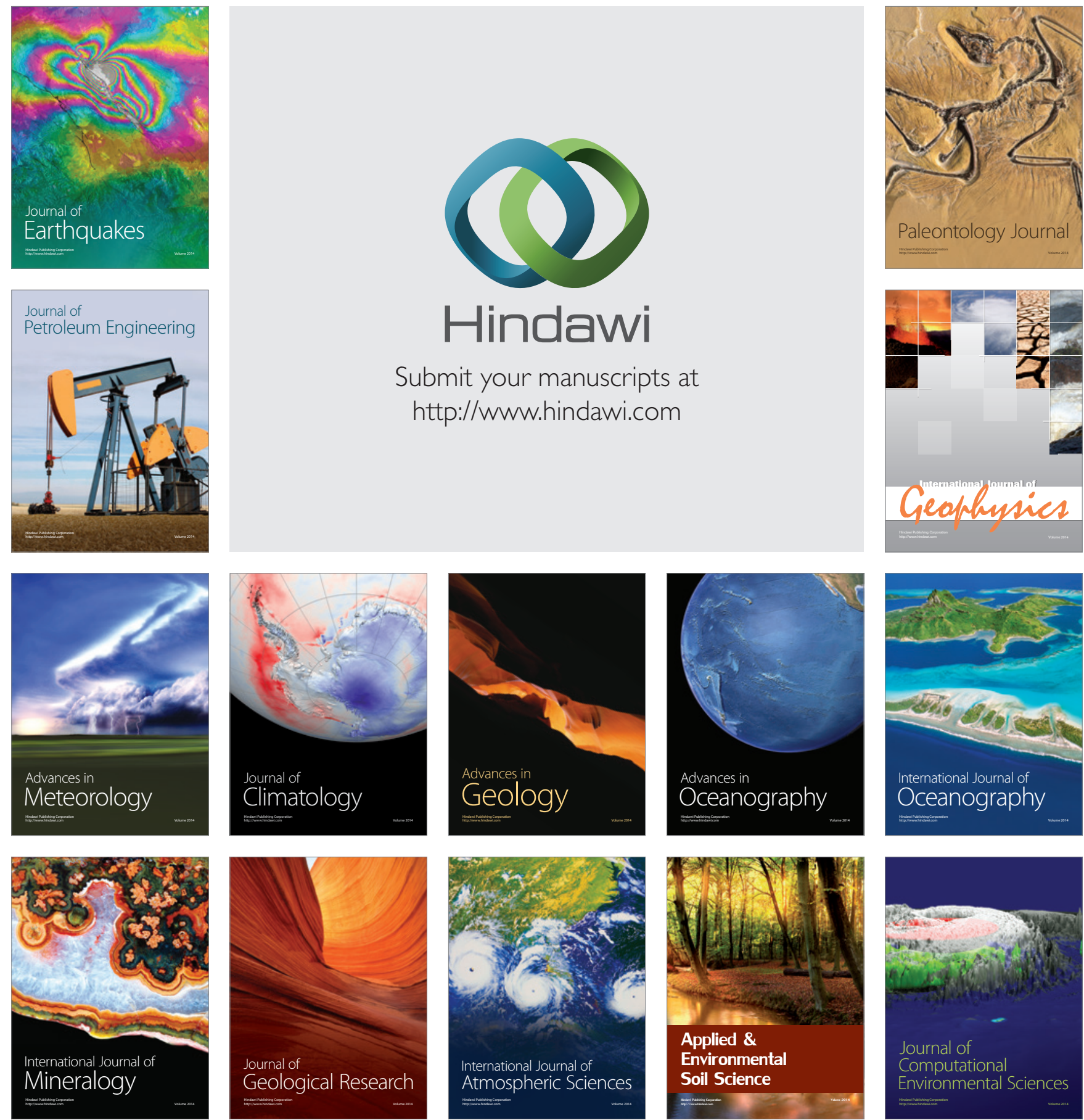